\title{
ESTRUTURA GENÉTICA DE CASTANHA DO BRASIL (Bertholletia excelsa H.B.K.) EM FLORESTA E EM PASTAGENS NO LESTE DO ESTADO DO ACRE
}

\author{
MEDIAN DE PARDO \\ Bióloga
}

Orientador: Prof. Dr. PAULO YOSHIO KAGEYAMA

Dissertação apresentada à Escola Superior de Agricultura "Luíz de Queiroz", Universidade de São Paulo, para obtenção do título de Mestre em Ciências, Área de Concentração: Ciências Florestais.

\author{
PIRACICABA \\ Estado de São Paulo - Brasil
}

Setembro de 2001 


\section{Dados Internacionais de Catalogação na Publicação (CIP) DIVISÃO DE BIBLIOTECA E DOCUMENTAÇÃO - Campus "Luiz de Queiroz"/USP}

\section{Pardo, Median de}

Estrutura genética de castanha do brasil (Bertholletia excelsa H.B.K) em floresta e em pastagens no leste do estado do acre / Median de Pardo. - - Piracicaba, 2001.

72 p. il.

Dissertação (mestrado) - - Escola Superior de Agricultura Luiz de Queiroz, 2001. Bibliografia.

1. Castanha-do-pará 2. Diversidade genética 3. Floresta tropical úmida 4. Pastagem I. Titulo

CDD 634.575

Termitida a cópia total ou parcial deste documento, desde que citada a fonte $-O$ autor 


\section{ERRATA}

$\begin{array}{llll}\begin{array}{l}\text { Página (s) } \\ \text { Toda dissertação } \\ \text { Resumo (vii) }\end{array} & \text { Linha } & \begin{array}{l}\text { Onde se lê } \\ \text { Castanha do Brasil } \\ \text { A taxa de cruzamento } \\ \text { tm)... }\end{array} & \begin{array}{l}\text { Leia-se } \\ \text { Castanheira } \\ \text { Para estimativa da taxa de cruzamento } \\ \text { (tm) utilizou-se 4 locos polimórficos. }\end{array} \\ \begin{array}{llll}\text { O resultado obtido foi alto para as ..... } \\ \text { 12 a } 54\end{array} & \begin{array}{l}\text { 29 e } 21 \\ \text { incluir }\end{array} & \begin{array}{l}\text { 150 ha e 1.500 ha } \\ \text { Não compõe o texto }\end{array} & \begin{array}{l}50 \text { ha e 500 ha } \\ \text { Incluir dados de Kanashiro 1999 }\end{array}\end{array}$


Às "populações tradicionais" da Floresta Amazônica, principalmente, do Estado do Acre dedicado este trabalho, pois fizeram de suas vidas uma história de luta na conservação do ambiente em que vivem. Através de luta e mortes conseguiram um passo histórico, a criação das Reservas Extrativistas (RESEXs) em nosso País. 


\section{Agradecimentos}

À Deus por ter colocado pessoas maravilhosas e diversas situações durante o mestrado que me auxiliaram a crescer.

Ao Dr. Paulo Y. Kageyama, pela orientação e oportunidade de trabalharmos juntos.

Ao CNPq que financiou minha bolsa de estudo, ao WWF - Natureza e Sociedade que financiou parte dessa pesquisa e ao Laboratório de Reprodução e Genética (LARGEA) que colaborou com toda infra-estrutura do laboratório necessários a essa pesquisa, meus agradecimentos. Ao Parque Zoobotânico ( $P Z)$ junto a Universidade Federal do Acre (UFAC) e Associação dos Moradores das Reservas Extrativistas de Xapuri (AMOREX), pela parceria.

Ao Sr. Olivio por ter cedido a área na qual foi realizada este estudo e sua sede para alojamento. Ao Nilson Teixeira Mendes pela habilidade de mateiro e amizade e ao Edmilson Silva pelo auxilio no plantio das amêndoas e todo apoio, sou grata.

Aos meus amigos Daisy Silva pelo por todo apoio concedido durante o mestrado e, ao Osvanilsom Veloso pela tradução do summary, sou grata.

A equipe técnica do Laboratório de Reprodução e Genética de Espécies Arbóreas - LARGEA: Elza, Gabriel, Andréa e Éster, agradeço o apoio dado à execução desse trabalho no laboratório e ao Gelson que preparou o substrato para o plantio das progênies.

Aos meus colegas de trabalhos: Helena Maltez pela amizade e correção da tese, sou imensamente grata pelas suas sugestões. A Giuliana Vasconcelos. pelo auxilio na extração das enzimas. Ao Luciano Ribas pelo auxilio na interpretação dos padrões de géis e sugestões. Ao Flavio Gandara e Alexandre coelho pelo número de progênies a ser utilizado. Alexandre Magno pelo auxilio orientações estatísticas e sugestões, muito obrigado. A Marta Negrão, Cristina Lacerda, Beatriz Perecin e Lucia Wadt pelo companheirismo e sugestões, sou grata. Ao Wilian Flores pelo manuseio da imagem do local de estudo.

A Sueli e Moisés Oliveira por receber em sua casa e me encorajarem. A rmuitas outras pessoas amigas e a minha família, não menos importantes que as demais nesse processo: Sania Lucia, Natal Gonçalvez e Ronaldo Weigand, agradeço de coração. 


\section{SUMÁRIO}

Página
RESUMO

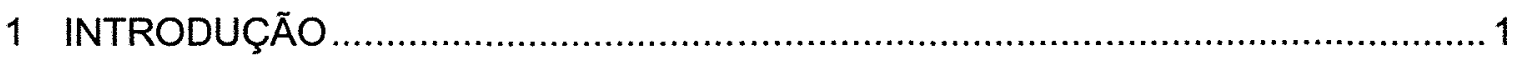

1.1 Perguntas deste estudo ........................................................................ 3

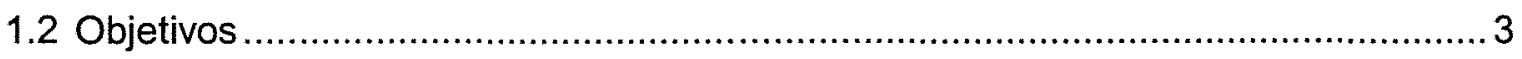

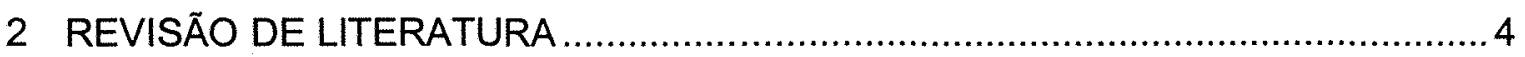

2.1 Descrição, Uso e Ocorrência de Bertholletia excelsa .......................................... 4

2.2 Biologia Reprodutiva de Bertholletia excelsa...................................................... 5

2.3 Fragmentação, Bertholletia excelsa e Legislação............................................. 10

2.4 Estrutura e Diversidade Genética............................................................... 12

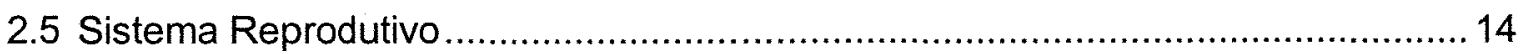

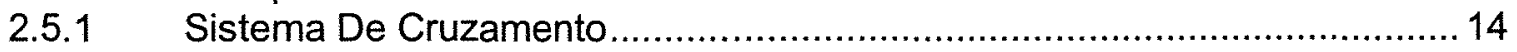

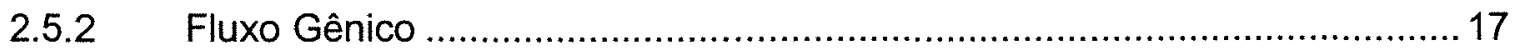

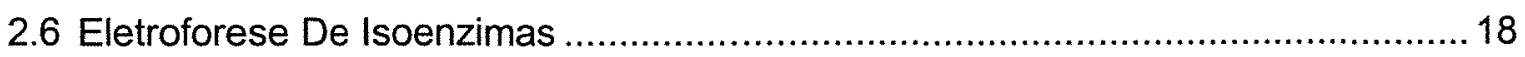

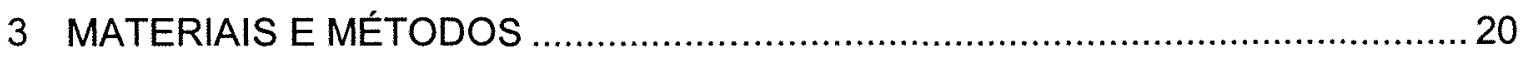

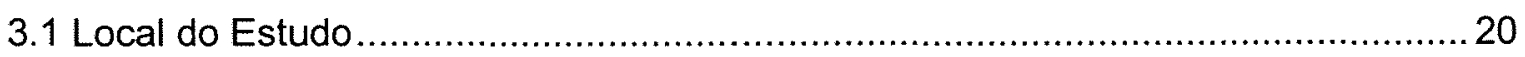

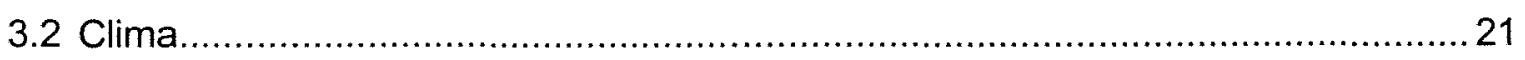

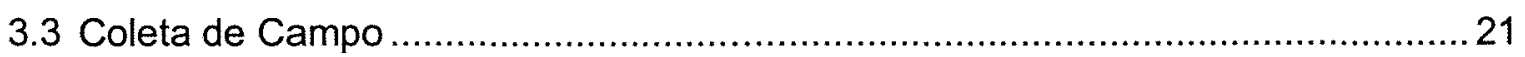

3.4 Viveiro: Plantio das Sementes para Obtenção de Progênies ............................. 22

3.5 Desenvolvimento de Protocolo para Eletroforese de Isoenzima de Bertholletia

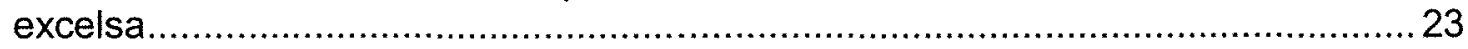

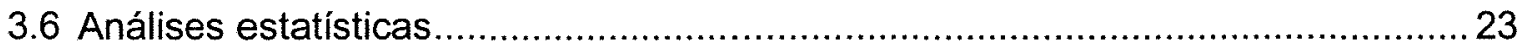

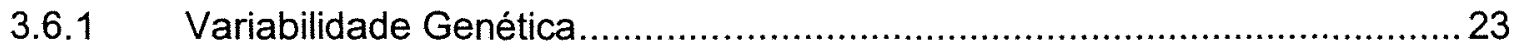

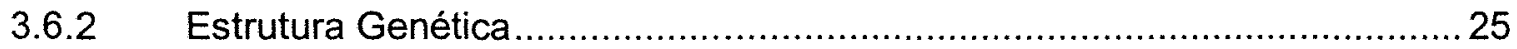

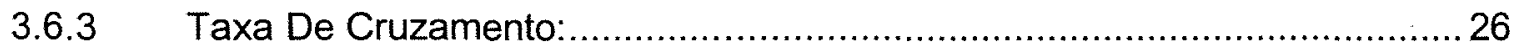

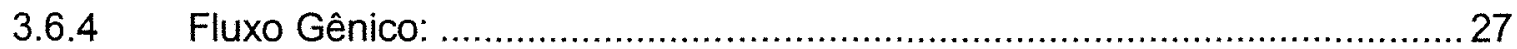

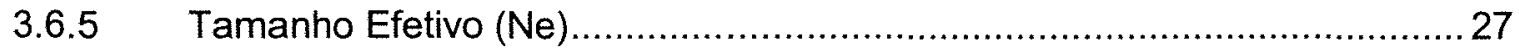




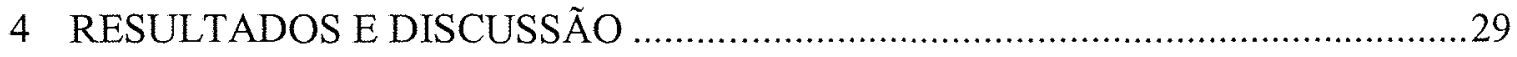

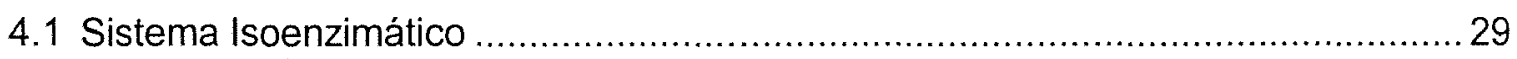

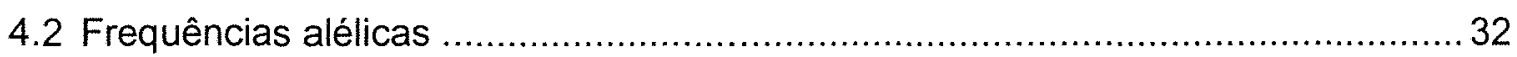

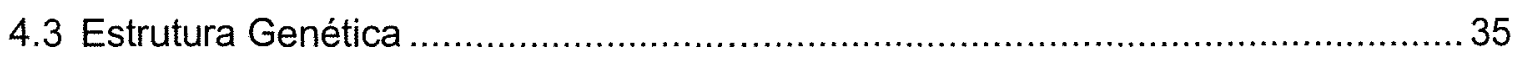

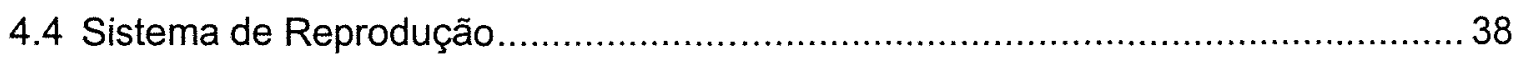

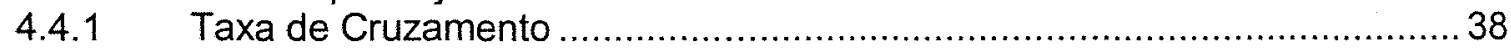

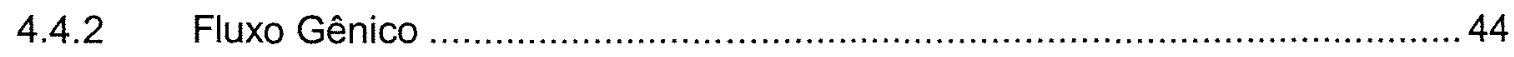

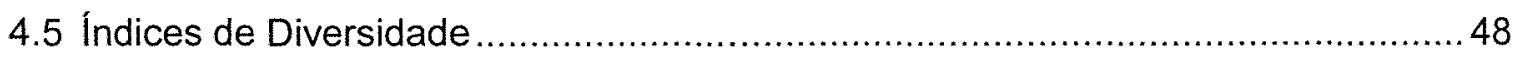

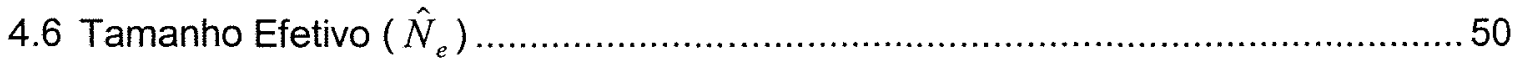

4.7 Conservação e manejo de Bertholletia excelsa ............................................. 52

4.8 Sugestões Para Trabalhos Futuros com Bertholletia excelsa...............................55

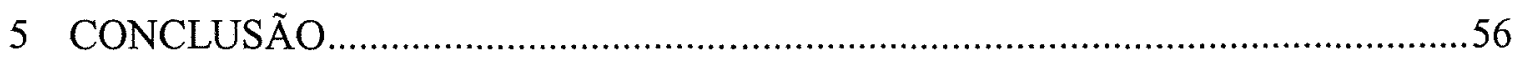

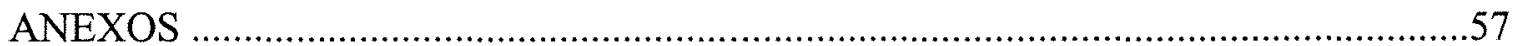

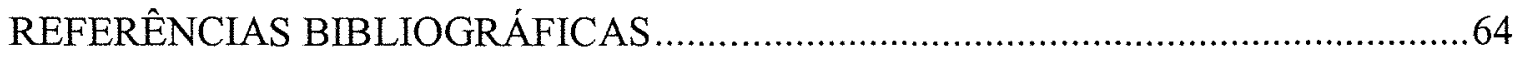




\section{ESTRUTURA GENÉTICA DE CASTANHA DO BRASIL (Bertholletia excelsa H.B.K.) EM FLORESTA E EM PASTAGENS NO LESTE DO ESTADO DO ACRE}

Autora: MEDIAN DE PARDO

Orientador: Prof. Dr. PAULO YOSHIO KAGEYAMA

\section{RESUMO}

Bertholletia excelsa, conhecida vulgarmente como Castanha do Brasil, é endêmica da Região Amazônica. A espécie é protegida por lei de corte no Brasil, mas mesmo com proteção a fragmentação de florestas em áreas de ocorrência da espécie têm causado isolamento e morte de milhares de Castanha do Brasil. A fragmentação de florestas trás alguns efeitos imediatos na estrutura de reprodução. Com a finalidade de estudar alguns efeitos da fragmentação na estrutura genética de $B$. excelsa escolheu-se três subpopulações no leste do Estado do Acre. A região localiza-se entre a $\mathrm{Br}$. 317 e o Projeto de Assentamento Agroextrativista Cachoeira no Município de Epitciolândia. Analisou-se Castanha do Brasil em Floresta, Pastagens com 2 e 4 anos de formação (P2 e P4). A estimativa dos parâmetros genéticos foi obtida por meio da técnica de eletroforese de isoenzimas em gel de amido. Analisou-se 30 árvores adultas e 15 progênies de 10 plantas de cada subpopulação. Foram utilizados 9 sistemas enzimáticos (SK, LAP, 6PGDH, G6PDH, DIA, PRX, EST, FEST, $\mathrm{MDH}$ ), totalizando 13 locos; destes, cinco foram monomórficos e os demais polimórficos. Na geração progênies, os locos Prx-4 e Est-2 tiveram suas frequências alélicas alteradas em relação as matrizes e detectou-se presença de alelo raro nas matrizes das subpopulações floresta e $\mathrm{P} 4$. A divergência genética $(\hat{\theta} \mathrm{p})$ entre as três populações foi baixa, apenas 0,020 (matrizes) e 0,027 (progênies). Subpopulações 
duas a duas mostraram maior distância genética entre floresta $x$ P4 $(0,059)$, intermediária entre floresta x P2 $(0,021)$, e baixa entre P2 x P4 $(0,008)$. A taxa de cruzamento $\left(t_{m}\right)$ foi alta para as três subpopulações: 1,0 (P2) e 0,93 (P4 e floresta), indicando que o sistema de cruzamento é predominantemente alógamo. O fluxo gênico foi maior entre floresta x P2 $(2,80)$ e P2 x P4 $(9,28)$ e, menor entre floresta x P4 $(0,98)$. Isso evidencia que no passado, o fluxo gênico era amplo suficiente para contrapor os efeitos de deriva genética. Atualmente, as condições ambientais não são homogêneas e, futuramente, a $\hat{\theta} \mathrm{p}$ entre as mesmas pode aumentar. Os índices de diversidade foram: $H_{e}$ entre 0,123 (floresta) a 0,146 (P4) nas matrizes e 0,105 (floresta) a 0,149 (P4) nas progênies. $O H_{e}$ médio foi de 0,133 (matrizes) e 0,123 (progênies); número médio de locos polimórficos e alelos foi de $35,90 \%$ e $40,0 \%$ e 1,36 e 1,40 , respectivamente. $O$ coeficiente de endogamia $\left(\hat{F}_{\text {is }}\right)$ foi levemente positivo apenas para as progênies da P2 $(0,086)$. Entretanto, as demais subpopulações e gerações apresentaram coeficiente negativo ou zero, indicando não haver parentesco. O tamanho efetivo $\left(\hat{N}_{e}\right)$ obtido para matrizes foi praticamente igual ao $\mathrm{N}$ amostrado (30) e para progênies foi 31,3 (floresta), 63,0 (P2) e 49,9 (P4). Os $\hat{N}_{e}$ apresentam-se próximo e dentro de famílias de meios irmãos, indicando que a maioria dos cruzamentos resultam de cruzamentos com pais diferentes. Para conservação da espécie sugere-se o estabelecimento de várias reservas genéticas com 150 ha e 1.500 ha. Como sugestão de manejo em áreas de ocorrência da espécie a serem fragmentadas, propõe-se a permanência da vegetação natural ao redor das populações com corredores ecológicos interligados com a floresta. 


\title{
GENETIC STRUCTURE OF BRASIL NUTS (Bertholletia excelsa) H.B.K. IN FOREST AND PASTURES IN THE EASTERN OF ACRE, BRASIL
}

\author{
Author: MEDIAN DE PARDO \\ Adviser: Prof. Dr. PAULO YOSHIO KAGEYAMA
}

\section{SUMMARY}

Bertholletia excelsa, more commonly known as Brazilian Nut, is endemic from the rain forest. In Brazil, the species are protected by a logging law, but despite the protection, the fragmentation of forests in areas in which the species are found has caused the isolation and death of thousands of Brazilian nut trees. The fragmentation of forests brings a certain number of immediate effects on the reproduction structure. Aiming at studying some of the effects of the fragmentation in the genetic structure of $B$. excelsa it has been selected three populations of the species in the Eastern part of the state of Acre. The region is situated between the road BR-317 and the Extrativist Settlement Project Cachoeira in Epitaciolândia. It has been analyzed Brazilian nut in forest, pasture with 2 and 4 years of formation (P2 e P4). The estimation of genetic parameters was obtained through the eletroforetic de isosymes in starch gel technique. An amount of 30 adult trees and 15 progeny trees in 10 families of each population were analyzed. It has been used 9 enzymatic systems (SK, LAP, 6PGDH, G6PDH, DIA, PRX, EST, FEST, MDH), in a sum of 13 locus from which 5 were monomorfic and the others polimorfic. In the progeny generation, the locus Prx-4 and Est-2 had their frequencies altered in relation to their matrixes and was detected the presence of a rare allelic in the matrixes of the forest sub-population and P4. The 
genetic divergence $(\hat{\theta} \mathrm{p})$ between the three populations was low, only 0,020 (matrixes) and 0,027 (progeny species). Subpopulations two by two reveals a bigger genetic distance between forest and P4 $(0,059)$, intermediary between had a rate forest $x$ P2 $(0,021)$ and smaller between P2 x P4 $(0,008)$. The rate of multiloc $\left(t_{m}\right)$ crossing was high for the three populations: 1,0 (P2) e 0,93 (P4 and forest), indicating that the crossing system is predominantly out-crossing. The flow gene was higher between forest $\times$ P2 $(2,80)$ and P2 $\times$ P4 $(9,28)$ and smaller between forest $\times$ P4 $(0,98)$. It demonstrates that in the past, the genetic flux was wide enough to counteract the effect of genetic drift. Nevertheless, the environmental conditions are not currently homogeneous and, in the future, the $\hat{\theta} \mathrm{p}$ among them might increase. The diversity rates revealed $H_{e}$ of 0,123 (forest) to $0,146(P 4)$ in the matrixes and of 0,105 (forest) to $0,149(\mathrm{P} 4)$ in the progeny species. The $\mathrm{H}_{\mathrm{e}}$ rate was of 0,133 to the matrixes and 0,123 in the progeny species; the average number of polimorfic loci and allelic was of $35,90 \%$ and $40,0 \% \mathrm{~m}$ and of 1,36 and 1,40 , respectively. The coefficient of endogamy $\left(\hat{F}_{\text {is }}\right)$ was slightly positive only to the progeny species of P2 $(0,086)$. However, the other subpopulations, matrixes as well as progeny species presented a negative coefficient or zero, indicating no relationship inbreeding among them. The effective size $\left(\hat{N}_{e}\right)$ obtained to matrixes of the three populations was quite the same to the $N$ shown (30). The $\hat{N}_{e}$ achieved for the progeny species was 31,3 (forest), 63,0 (P2) and 49,9 (P4). The $\hat{N}_{e}$ seemed to be close and inside the families half-sibling, indicating that most of the crossings derive from crossing with different parents. Suggested the establishment of several areas genetic reserves with 150 ha and 1.500 for conservation of the species. As a suggestion for management, in areas where the species can be found and which are going to be fragmented, it is proposed the permanence of natural vegetation around the populations with ecological corridors connecting with the forest. 


\section{INTRODUÇÃO}

As Florestas Tropicais representam apenas $7 \%$ da superficie terrestre, mas contêm mais da metade das espécies do planeta (CGIAR, 1994; Wilson, 1988). Essa alta diversidade proporciona interações entre as plantas e outros organismos tais como as relações de polinização, dispersão, parasitismo, simbiose, predação (Kageyama \& Gandara 1993) e o sustento à milhares de pessoas que vivem nesse ambiente.

Até a década de 1970, a grande maioria dos moradores da Região Amazônica no Brasil residia na floresta e subsistia da atividade extrativista, principalmente da Seringa (Hevea brasiliensis) e da Castanha do Brasil (Bertholletia excelsa), ficando conhecida como "povos da floresta", dentro das campanhas para assegurar seus direitos de posse da terra e defender o meio ambiente da região. No final da década de 1970, com o incentivo do Governo Federal para implantação de projetos agropecuários e infraestrutura, muitas áreas da Floresta Amazônica foram completamente transformadas em pastagens, cultivos, vias de acesso e centros urbanos (Bentes et al., 1988), sem estudo ou planejamento. A taxa de desmatamento na Amazônia Brasileira tem sido acelerada nos últimos anos, dados de 1995 a 1997 indicam desmatamento sobre uma área de 2 milhões de hectare por ano (Laurance, 1998).

Na região de Xapuri, no Estado do Acre, o acelerado processo de devastação em áreas extrativistas impulsionou os "povos da floresta" a se organizarem e a lutarem pelo direito do extrativismo e conservação das áreas em que residiam. Por meio da pressão desse movimento (empate), liderado pelo seringueiro Chico Mendes, o Governo Federal regularizou áreas ocupadas por extrativistas em Assentamentos Extrativistas e Reservas Extrativistas (RESEXs), sendo a Reserva Extrativista do Cachoeira a primeira a ser implantada na Amazônia (Viana et al., 1998). Esse ato foi um marco na história extrativista em favor dos direitos das comunidades tradicionais e da floresta (Viana, 1998). As RESEX's são unidades de conservação, implantadas como um sistema de utilização da terra que concilia a proteção da floresta às reais necessidades e direitos dos "povos da floresta", visando melhorar seu padrão de vida (Allegretti, 1989). 
O processo de fragmentação na Floresta Amazônica Brasileira em áreas de ocorrência natural de Castanha do Brasil (Bertholletia excelsa) causou e tem causado o isolamento de muitos indivíduos ou populações inteiras da espécie. No intuito de preservar a espécie, visando a economia das comunidades tradicionais e da Amazônia, a lei federal 4.771 [código florestal] proibe o corte da mesma. Quando há desmatamento, muitos proprietários cumprem a lei, evitando o corte da Castanha do Brasil. Entretanto, indivíduos remanescentes da espécie que permanecem isolados em grandes áreas abertas, decorrentes do desmatamento, declinam a produção de frutos e, em um prazo de 10 anos, estão praticamente todos mortos. O fogo, utilizado na região para limpeza e renovação de áreas recém desmatadas, pastagens e terras agriculturáveis, destrói habitats dos polinizadores e muito provavelmente é o causador da morte dos remanescentes de Castanha do Brasil.

Muitos consideram os indivíduos remanescentes como "semi-mortos" por acreditarem que não se reproduzem nesse novo ambiente. Outros acreditam que os polinizadores não saem da mata para efetuar a polinização em áreas abertas (como no caso de extensas áreas de pastagens ou agricultura), sendo esse o motivo para a ausência ou baixo número de frutos produzidos pelos remanescentes nesse novo ambiente. Entretanto, ainda não há trabalho publicado nesse enfoque.

Neste estudo, queremos conhecer, principalmente, o sistema de reprodução e algumas das relações que os remanescentes de Castanha do Brasil em pastagens mantêm com os que estão em floresta. Desta forma, estimamos dados da estrutura genética de árvores de Castanha do Brasil em floresta e em duas pastagens com idades diferentes de formação. Partimos do pressuposto de que a floresta e as duas pastagens com árvores remanescentes de Castanha do Brasil, constituiam uma população contínua. Essa área foi fragmentada, originando assim as pastagens com indivíduos remanescentes de Castanha do Brasil que não puderam ser retirados por força da Lei Federal 4.771. Consideramos as amostras coletadas de cada uma dessas três áreas como "subpopulações".

Os dados foram obtidos utilizando marcadores genéticos alozímicos, a partir dos quais foi possível estimar os seguintes parâmetros genéticos: taxa de cruzamento, diversidade genética e o fluxo gênico entre as subpopulações. Diante dos dados, discutiu-se as diferenças entre as subpopulações da floresta e as em pastagens sob uma perspectiva de elaboração de estratégias de conservação e manejo para a região 
do estudo, bem como discutir a efetividade da Lei Federal 4.771 na conservação da espécie.

\subsection{Perguntas deste estudo}

a) Os remanescentes de Castanha do Brasil em pastagens produzem frutos?

b) A diversidade apresentada pelas três subpopulações sugerem tratar-se de apenas uma única população?

c) As taxas de cruzamento obtidas para as subpopulações em pastagens diferem da obtida na subpopulação floresta?

d) Ocorre aumento de endogamia nos novos indivíduos originados pelos remanescentes em pastagens?

e) Ocorre fluxo gênico entre as árvores de Castanha do Brasil da floresta com as da pastagens?

\subsection{Objetivos}

Geral:

Investigar a diversidade genética e o sistema de reprodução das árvores de Castanha do Brasil (Bertholletia excelsa), por meio da técnica de eletroforese de isoenzimas, em área de floresta natural e remanescentes isolados em pastagens, sendo este último grupo, resultado da intervenção humana.

\section{Especificos:}

a) Estimar a variabilidade genética dentro de três subpopulações de Castanha do Brasil, comparando-as entre si;

b) Estimar a divergência genética entre as subpopulações em estudo;

c) Estimar a taxa de cruzamento de cada subpopulação, comparando-as;

d) Estimar o fluxo gênico entre as subpopulações de Castanha do Brasil em floresta e em pastagens. 


\section{REVISÃO DE LITERATURA}

\subsection{Descrição, Uso e Ocorrência de Bertholletia excelsa}

Lecythidaceae é uma família com árvores muito grandes nos trópicos, sendo bem conhecida por duas espécies que possuem nozes comestiveis: Lecythis usitata - sapucaia, e Bertholletia exelsa - Castanha do Brasil (Prance \& Mori, 1978).

A Castanha do Brasil é endêmica da região Amazônica e encontra-se desde $O$ alto Orenoco $\left(5^{\circ}\right.$ lat. Norte) até $\mathrm{O}$ alto Beni $\left(14^{\circ}\right.$ lat. Sul), compreendendo a Venezuela, Brasil, Colômbia, Peru e Bolívia. Localiza-se em maiores concentrações na porção Brasileira, principalmente no planalto que separa a bacia formada pelos afluentes do baixo Amazonas, alto Tocantins e alto Moju, e em terras altas ao norte do rio Jari: no Estado do Pará (rio Trombetas, Tapajós, Xingu, Tocantins e afluentes); Maranhão, Amazonas (rio Amazonas, Madeira, Negro, Purus e afluentes) e Acre (rio Purus, rio Acre, laco e Abonã), e Mato Grosso (rio Araguaia) (Neves, 1938 e Muller, 1995).

A espécie é conhecida vulgarmente por várias denominações: Castanha do Brasil como citação mais recente, Castanha do Pará, Castanha, Castanheira, Castanhaverdadeira, Amendoeira da América e Castanha-mansa. Na sinonímia indigena, Eraí para os Caruahis, Iniá para os índios Chipayas, e Tocary para os Parecís. No vale do Orenoco era conhecida como Tucá, Turury, Uá, Yuvia ou Juvia, Nhá e Niá. Como sinonímias estrangeiras podemos citar: Nuez del Brasil (Latino-americano), Noix du Bresil (Franceses) e Brazil nuts ou Pará nuts (Anglo saxões) (Almeida, 1963 e Lorenzi, 1992). Nesse trabalho usaremos como denominação vulgar, Castanha do Brasil, e ao referir-se a espécie no contexto amplo, usaremos seu nome científico, B. excelsa.

O uso da espécie foi bem variado no passado, atualmente limita-se, ao fruto. A casca do fruto e da amêndoa e utilizada como combustivel para afugentar as pragas, defumação da borracha, carvão, artesanato na confecção de porta jóias, saboneteiras, vasos, farinheiras, cinzeiros, lembranças e como remédio para hepatite e azia. A castanha é rica em proteinas e calorias. Desta, pode-se obter o leite, sendo de igual valor nutricional ao leite de vaca, pois contém minerais e aminoácidos completos. Também 
pode-se usar na produção de farinha, sorvete, doce, óleo para fabricação de sabão e para dar brilho ao cabelo e como chá medicinal para diarréia (Souza, 1963; Kainer, 1997 e Shanley et al., 1998).

A densidade de Bertholletia excelsa apresentada em termos de número de individuos por hectare em trabalhos científicos varia de acordo com sua área de ocorrência e com a metodologia adotada para o levantamento. Estimativas da densidade obtidas para a espécie na Área Indígena Kayapó, no Sudeste do Pará por Baider (2000), ficaram em torno de 3,3 ind./ha para plântulas e indivíduos adultos. Viana (1998) na região de Xapuri no Estado do Acre encontrou 3,1 ind./ha. Rijsoort et al. (1993) estudaram o impacto da extração de Bertholletia excelsa em sua estrutura populacional em 14 ha distribuídos em 2 áreas de floresta primária da Amazônia Boliviana. Na primeira área encontraram 31 indivíduos, e na segunda 25 individuos, distribuídos em classes de tamanho maior que $1 \mathrm{~cm}$. Salomão (1991), ao analisar a estrutura e densidade de Bertholletia excelsa nas regiões de Carajás e Marabá, no Estado do Pará, em 22 inventários (1ha cada), encontrou densidade absoluta de 1 a 8 indivíduos/ha em 13 inventários. Generalizando, pode-se dizer que, sendo que em florestas naturais de ocorrência de $B$. excelsa a densidade média é de 0,1 a 2,5 indivíduos/ha, em regiões de maciços, essa densidade pode atingir até 10 a 15 árvores por hectare (Shanley et al., 1998).

\subsection{Biologia Reprodutiva de Bertholletia excelsa}

A espécie é caracterizada como semidecídua, heliófita em estágio jovem e adulto, característica de mata de terra firme, sendo rara a ocorrência em terras baixas ou temporariamente inundáveis. Ocorre em determinados locais em grande frequência, formando as "reboleiras" ou "Castanhais" (Lorenzi, 1992). Possui altura entre 30 a $50 \mathrm{~m}$, chegando às vezes a $60 \mathrm{~m}$, sobressaindo no dossel. Seu diâmetro varia de 100 a $400 \mathrm{~cm}$ e suas folhas são simples e glabras, medindo de 25 a $35 \mathrm{~cm}$ de comprimento (Lorenzi, 1992 e Shanley et al., 1998). Estima-se que essas imponentes árvores da região Amazônica atinjam cerca de 800 (Shanley et al., 1998) a 1000 anos (Camargo et al., 1994).

A floração da espécie é constituída por inflorescências do tipo rácimo ou panícula de rácimo (Cavalcante, 1988). Suas flores são caracterizadas por muitos estames soldados na base formando um anel assimétrico - zigomórfico (Mori \& Prance, 1981) e um chapéu em forma de elmo que contém os estaminódios recobrindo o eixo floral (Moritz, 
1984). O ovário é ínfero e o número de lóculos pode ser de quatro (Moritz, 1984), cinco (Maués \& Oliveira 1999) ou variar de três a seis (Mori \& Prance 1990a), totalizando de 16 a 25 óvulos. Possui $2 n=34$ cromossomos. Como recompensa aos visitantes, oferecem em suas flores pólen e néctar e aroma levemente adocicado.

A floração da espécie está intimamente ligada às condições climáticas de cada zona fisiogeográfica, ocorrendo, variações quanto à época e periodo de floração. Os Castanhais plantados no Amazonas e os do Estado do Acre possuem época de floração um pouco diferente dos localizados no Pará (Muller, 1995). Moritz (1984) cita que a espécie no Estado do Acre floresce primeiro que no Pará mas, de modo geral, a floração encontrase dentro do período de Agosto a Fevereiro.

O tempo de floração de cada árvore de Castanha do Brasil pode durar de um a quatro meses (Baider, 2000) e seu florescimento pode ser classificado como maciço, pois todas as espécies de Lecythidaceae emergentes ou de dossel apresentam esse evento (Mori et al., 1978). Segundo Bullock (1985) o florescimento maciço é uma estratégia de reprodução que funciona como atração para seus polinizadores. Apesar de sua estratégia de florescimento, estima-se que apenas $0,4 \%$ (Pinheiro \& Albuquerque, 1968) a $4,4 \%$ (Moritz, 1984) do total de flores produzidas resultam em frutos.

As características das flores da familia Lecythidaceae Neotropicais, de modo geral, enquadram-se na síndrome de polinização denominada por melitofilia (Mori \& Prance, 1990a), que se caracteriza pela dependência de abelhas de grande porte, atraídas pelo odor levemente adocicado ou pela coloração das flores, que contém néctar rico em açúcares (Faegri \& Van Der Pijl, 1979). A fecundação das flores dessa família, aparentemente segundo Mori \& Prance (1981), depende do transporte de pólen da flor de uma árvore para flor de outra por meio de vetores animais.

Janzen (1971) relata abelhas Euglossinae forrageando e polinizando diversas espécies pertencentes a várias familias, dentre elas, Lecythidaceae. Descreve ainda que essas abelhas forrageiam a longas distâncias em florestas tropicais, chegando a $23 \mathrm{Km}$ de distância de seus ninhos e visitando algumas plantas repetidamente ao longo de sua rota de alimentação.

A familia Lecythidaceae, no novo mundo, têm suas espécies separadas em dois grande grupos: as com androceus simétricos e as com androceus assimétricos capuzes enrolados (Mori \& Prance, 1981). Os referidos autores citam as Euglossinae como principais polinizadoras das Lecythidaceae que produzem néctar e possuem capuzes 
enrolados, pois somente essas grandes abelhas com lingua comprida conseguem empurrar o capuz (elmo) e sugar o néctar que se encontra no ápice do capuz enrolado. Acreditam também que o capuz seja uma resposta às pressões de seleção exercida ao longo da sua evolução, pelas abelhas Euglossinae. Dessa forma, somente polinizadores especializados conseguem obter os recursos oferecidos - pólen e néctar - pelas espécies com característica assimétrica nessa família, lembrando ainda que esse grupo de planta, bem como as abelhas Euglossinae, são restritas às regiões neotropicais (Mori \& Prance, 1981).

Trabalhos realizados sobre biologia da polinização de Bertholletia excelsa, relatam como principais polinizadoras as abelhas grandes (Tabela 1). No grupo de abelhas observado por Muller et al. (1980), os gêneros Bombus e Centris são citados com sendo os principais e mais eficientes polinizadores. Essa afirmação do autor é atribuída ao fato dessas abelhas realizarem um maior periodo de visita às flores já frequentadas por outras abelhas, e também às flores que não foram visitadas por nenhuma outra espécie de abelha.

Nelson et al. (1985) observaram os visitantes das flores de Castanha do Brasil em árvores plantadas em área aberta próxima a floresta secundária e natural em Manaus. Encontraram três gêneros de abelhas distribuídos em cinco espécies, sendo machos e fêmeas (Tabela 1). Observaram que esses agentes carregavam, além do pólen da espécie estudada, pólen de plantas que se encontravam nas áreas circunvizinhas, ou seja, floresta secundária e natural. Os dados deste trabalho nos indicam que essas cinco espécies de abelhas possuem capacidade de forragear área fechada, como uma floresta, $e$ área modificada, como floresta secundária. Entretanto, segundo esses autores, o mesmo evento pode não ocorrer em ambientes tão abertos como as extensas áreas de pastagens. Maués (1999) observando a entomofauna polinizadora da Castanha do Brasil nos municípios de Belém no Estado do Pará encontrou oito espécies de abelhas distribuídas em cinco gêneros (Tabela 1). 
Tabela 1. Visitantes das flores de Bertholletia excelsa em plantios em diferentes regiões na Amazônia Brasileira. Piracicaba 2001.

\begin{tabular}{ll}
\hline \multicolumn{1}{c}{ VISITANTES } & \multicolumn{1}{c}{ AUTORES } \\
\hline Centris $^{*}$ & Muller et al., 1980 \\
Centris similis & Maués, 1999 \\
Bombus* $^{*}$ & Muller et al., 1980 \\
Bombus brevivillus $^{*}$ & Maués, 1999 \\
Bombus transversalis $^{*}$ & Maués, 1999 \\
Epicharis (Hoplepicharis) affinis* $^{*}$ & Maués, 1999 \\
Epicharis rustica $(f)$ & Nelson et al., 1985; Muller et al., 1980; e Maués, 1999 \\
Epicharis umbraculata $(f)$ & Nelson et al., 1985 \\
Eulaema cingulata $(m)$ & Nelson et al., 1985; e Maués, 1999 \\
Eulaema nigrita $(m / f)$ & Nelson et al., 1985; Muller et al., 1980; e Maués, 1999 \\
Euplusia seabrai $(f)$ & Nelson et al., 1985 \\
Xylocopa & Muller et al, 1980 \\
Xylocopa frontalis * & Maués, 1999 \\
\hline
\end{tabular}

Fonte: Nelson et al. (1985), Muller et al. (1980) e Maués (1999).

$(f)=$ fêmea e $(m)=$ macho. $O^{*}$ simboliza os principais polinizadores, para Nelson et al. (1985) e Muller et al. (1980), e os mais freqüentes para Maués (1999).

O fruto de $B$. excelsa é capsular, do tipo pixídio arredondado, conhecido vulgarmente como "ouriço" (Moritz, 1984 e Cavalcante, 1988); leva em média 12 a 14 meses para completa maturação e consequente queda (Muller, 1995). Mori \& Prance (1981) consideram o fruto de B. excelsa como pixidio deiscente, mas funcionalmente indeiscente, pois necessita da ação de agentes dipersores com capacidade de abrir a espessa cápsula do fruto e do envoltório das sementes. Os principais agentes capazes de abrir o pixídio e dispersar as sementes são as cutias (Dasyprocta spp) e esquilos (Sciurus spp), segundo Mori \& Prance (1981), onde parte das sementes são comidas e outra parte é enterrada para consumo posterior, sendo realiza assim a dispersão.

"Os povos da floresta" supõem que muitas das sementes enterradas não são encontradas posteriormente pelos animais, devido ao esquecimento ou germinação das mesmas, mas ao atingir estadio de plântulas muitas são predadas pelos vários animais que a utilizam como alimentação. Baider (2000) relata que as cotias levam parte das sementes até certas distâncias, onde abrem um buraco de alguns centímetros de profundidade para enterrá-las, guardando como reserva futura. Algumas dessas sementes poderiam não ser removidas e, assim, teriam a oportunidade de germinar. Dessa forma, como dispersores das castanhas, as cotias influenciariam a distribuição das árvores adultas. 
Viana (1998) entrevistando para-florestais e seringueiros em XapuriAc, foi informado que animais como o quati, quatipuru, macaco prego, porquinho do mato e outros pequenos roedores agem como predadores e dispersores das sementes de $B$. excelsa. Inclusive, pode-se distinguir as diferentes marcas de dentes e o tipo de abertura feita nos ouriços para a retirada das amêndoas (Figura1 e 2), (Nilson Teixeira Mendes, 1999, comunicação e observação pessoais).

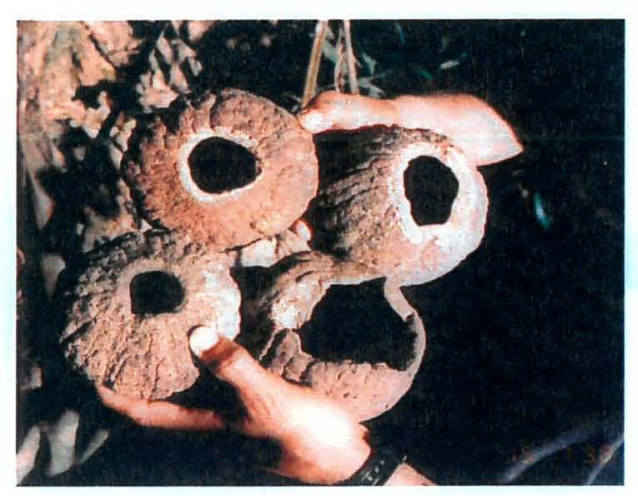

Figura 1 - Ouriços de Bertholletia excelsa roídos e quebrados por diferentes tipos de animais. Do polegar direito em sentido horário: 1) roído por cutia. 2) roído por paca. 3) quebrado por macaco prego. 4) roído por quatipuru. Foto: Median de Pardo

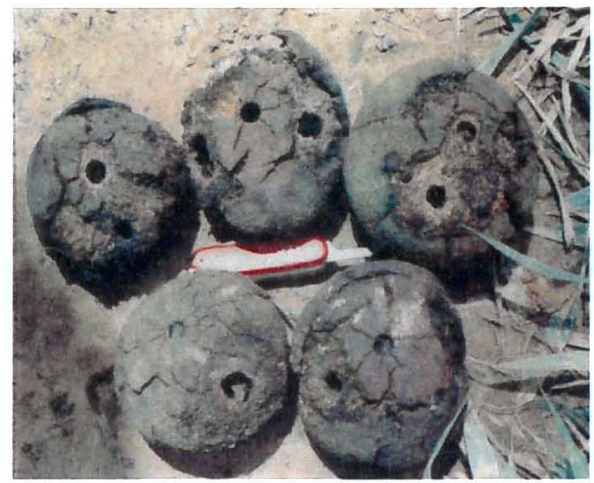

Figura 2 - Ouriços de Bertholletia excelsa furados por pica pau quando imaturos na copa da Castanha do Brasil. Foto: Median de Pardo

Em seu estudo sobre predação e dispersão de frutos de $B$. excelsa no sudeste do Estado do Pará, Baider (2000) identificou cinco potenciais predadores/dispersores: araras (Ara chloroptera), Pica-pau de pescoço vermelho (Campephilus rubricollis), Macaco-prego (Cebus apella), pequenos roedores (ratos) e Cotias (Dasyprocta agouti). Dentre esses agentes, as cotias e os macacos pregos foram os que levaram os frutos a maiores distâncias; entretanto, a autora classifica as cotias como principais dispersoras pela sua capacidade de deposição de sementes em sítios favoráveis à sua germinação e os demais agentes como eventuais dispersores.

No intuito de estudar citologia e taxa de fecundação, Moritz (1984) realizou um estudo da floração e frutificação em clones (um clone mãe e oito clones doadores) de $B$. excelsa no CPATU/EMBRAPA. Verificou que a espécie possui de 4 a 5 
locos e 15 a 29 óvulos por fruto e para que ocorra o desenvolvimento dos frutos até completa maturação é necessária a fecundação de 70 a $100 \%$ dos óvulos ou, em média, $85 \%$ do total de óvulos em um fruto.

Dos oito clones avaliados no trabalho de Moritz, contou-se um total de 2.129 frutos caídos prematuramente, os quais apresentaram diâmetros entre de 0,0 a 2,57 $\mathrm{cm}$. Destes, a grande maioria estava com 17 a $73 \%$ dos óvulos fecundados e apenas 19 frutos apresentaram de 77,5 a $85 \%$ de seus óvulos fecundados. Para o grupo de clones submetidos à autopolinização, não se observou nenhum desenvolvimento de fruto até a maturação. O autor comenta que parte da fecundação ocorrida nesses frutos caídos prematuramente pode ser decorrente de pseudocompatibilidade. Concluiu-se que quanto maior o nủmero de óvulos fecundados maior a probabilidade de desenvolvimento $e$ maturação do fruto em clones de Castanha do Brasil (Moritz, 1984). Esses dados confirmaram os previamente observados por Muller (1980), o qual notificou que, quando o fruto de $B$. excelsa atinge a taxa média de fecundação dos óvulos $(85,3 \%)$, o sistema fisiológico do indivíduo induz uma maior concentração de auxina visando assegurar a frutificação.

\subsection{Fragmentação, Bertholletia excelsa e Legislação}

Nas últimas décadas, a ação humana tem sido responsável por boa parte do desaparecimento de plantas e animais por meio da destruição de habitats, notadamente os de grande diversidade biológica como as Florestas Tropicais.

Intervenções na Amazônia Brasileira com fins agropecuário e madeireiro, principalmente no Estado do Acre, têm acontecido ainda de forma inadequada, sem planejamento e manejo. Essas atividades de substituição das florestas naturais por ambientes modificados, e a extração em massa de espécies madeireiras em áreas de ocorrência natural de Bertholletia excelsa, têm resultado em uma alta taxa de fragmentação e causado grande impacto sobre populações da espécie.

$B$. excelsa possui imunidade ao corte, por meio da lei federal 4.771 (15 de setembro de 1965 e a portaria 2.570 do IBDF de 22 de novembro de 1971), sendo evitada assim a comercialização da madeira. Também existe uma portaria que prevê a proibição do desmatamento em áreas de ocorrência natural de maciços da espécie (portaria de $n^{\circ} 449-P$ de $3 / 10 / 1987$ ). Em parte pode-se dizer que a lei federal tem sido 
cumprida e não ocorre comercialização legal da madeira, mas a restrição de desmatamento em áreas de maciço da espécie não é cumprida.

Em primeira instância pode-se supor que não é o desmatamento que provoca as graves conseqüências aos remanescentes de Castanha do Brasil, e sim os tratos utilizados para manejar a área desmatada. Ao desmatar uma área de floresta, árvores de Castanha do Brasil permanecem no local (em função da lei) totalmente desprovidas de vegetação adulta em sua circunvizinhança. $O$ fogo, por ser o recurso mais rápido e econômico para fazer a limpeza da área recém desmatada e renovação das mesma em anos susbsequentes, é constantemente utilizado pelos proprietários. Uma vez realizada a queimada nessas áreas, os troncos das árvores remanescentes de Castanha do Brasil são queimados e por sua resina ser altamente combustível (anexo 2), o fogo chega a atingir cerca de 20 a $30 \mathrm{~m}$ de altura, danificando a casca das árvores e o sistema fisiológico. Isto favorece 0 ataque de cupins e instalação de outros animais, contribuindo para a desvitalização das árvores remanescentes de Castanha do Brasil (obs. pessoal, 1998 e 1999 e Viana et al., manuscrito), e origina, segundo Kitamura (1984), os cemitérios de Castanha do Brasil.

O intuito da lei é o de preservar a espécie e seu ambiente em áreas de ocorrência natural de maciço. Apesar de ser de conhecimento público a trágica situação dos cemitérios de Castanhais até o presente momento nenhuma providência ou medida foi tomada para estabelecer um manejo adequado ou de proteção para os remanescentes em áreas desmatadas. Isso demonstra que a portaria 449-P não é praticada na integra e, apenas restringir o corte da espécie, não garante a vitalidade e perpetuação das árvores remanescentes de Castanha do Brasil.

Até o momento, a única medida tomada foi para a utilização da madeira morta de Castanha do Brasil em áreas desmatadas com fins à utilização em obras relevantes de interesse público (decreto $n^{\circ} 1.282$ de 19 de Outubro de 1994 , art. $4^{\circ} \mathrm{e}$ portaria $n^{\circ} 48$ de Julho de 1995 e, artigo 32 da Secção III), mas nenhuma medida foi tomada para a prevenção ou contenção da morte das árvores remanescentes de Castanha do Brasil.

A produção de frutos da espécie em pastagens parece possuir estreita relação com a idade de formação da pastagem, ou seja, quanto mais velha a pastagem menor densidade de frutos por área. Essa relação, provavelmente, não ocorre apenas em 
função da redução do número de matrizes devido à morte, mas também da diminuição de frutos por árvore.

O resultado da modificação de habitats realizada sem planejamento e estudos prévios pode ter implicações diretas na estrutura genética populacional de determinadas espécies. Assim, áreas que contêm populações pequenas, de modo geral, mantém níveis menores de variabilidade genética intrapopulacional e são mais suscetíveis à perda da variabilidade genética por deriva (Wright, 1931 e Nei et al., 1975). Deriva genética é a mudança na frequência gênica que ocorre inteiramente ao acaso em uma população finita. Todavia, em populações com tamanhos reduzidos esse processo torna-se bem mais rápido devido ao efeito acumulativo e tem como principais consequências evolutivas a perda da variação genética dentro de populações e a divergência genética entre populações (Futuyma, 1992).

A fragmentação de habitats pode causar perda da variação genética por duas vias: primeiro, através da redução do tamanho populacional, onde se cria gargalos genéticos ("bottlenecks") em função dos indivíduos remanescente conterem apenas uma amostra de "pool" gênico original; segundo, como conseqüência da redução da população ocorre perda contínua de alelos em função da deriva genética, caso permaneça isolada por muitas gerações (Souza, 1997).

Alguns estudos revelaram que os efeitos da redução na variação genética em função da redução no tamanho populacional e isolamento populacional, em três espécies herbáceas e uma arbórea, devem-se mais ao efeito gargalo do que a deriva genética (Young et al., 1996). O efeito gargalo, como já vimos, é proveniente da redução no número de indivíduos capacitados a manter a variabilidade dentro da população da espécie. Essa redução, ao que tudo indica, altera a composição de agentes polinizadores e dispersores, e tem como consequência modificações nos padrões de dispersão de pólen e semente (Foré et al., 1992), refletindo nos parâmetros relativos ao sistema de cruzamento e estrutura genética das populações.

\subsection{Estrutura e Diversidade Genética}

A estrutura populacional de uma espécie é formada pelo conjunto das caracteristicas demográficas e genéticas adquiridas com as interações dos mecanismos evolutivos e ecológicos (Martins, 1987). 
Os individuos de uma espécie raramente se distribuem homogeneamente no espaço. Quase sempre formam agregados, bandos, colônias, ou outro tipo de associação. Sua distribuição no espaço físico depende de alguns fatores como: a) limites estabelecidos por variáveis ecológicas; b) modo de reprodução e mecanismos de dispersão da espécie; c) eventos estocásticos que resultam na formação e extinção de populações ou em variações do seu tamanho efetivo; e d) variáveis ambientais que impõe diferentes coeficientes de seleção a cada genótipo (Robinson, 1998).

A estrutura genética de plantas apresenta niveis de variação genética entre e dentro de populações. Esses niveis são mantidos em função de fatores como o sistema reprodutivo, fluxo gênico, níveis de endogamia, seleção natural e deriva genética de uma determinada espécie (Hamrick, 1983; Richards, 1986 e Kageyama, 1990).

A variação genética é quantificada, geralmente, em termos do número de locos polimórficos por população, do número efetivo de alelos por locos, ou do número médio de locos heterozigotos por indivíduos (Weir, 1990). Segundo Hamrick (1983), características que influenciam a distribuição da variação genética são: o tamanho efetivo populacional, a distribuição geográfica da espécie, o modo de reprodução, o sistema de cruzamento, o mecanismo de dispersão de sementes e o tipo de comunidade na qual a espécie comumente ocorre.

Os estudos realizados com espécies arbóreas tropicais até o presente momento têm demonstrado que a história de vida e as características ecológicas das espécies refletem na variação intra e interpopulacional bem como na heterogeneidade de suas populações. De modo geral, as plantas mantêm a maior parte da variabilidade genética dentro das populações e uma heterogeneidade considerável para os níveis de variação interpopulacional e sistema de cruzamento predominantemente misto (Hamrick, 1983; Kageyama, 1990 e Hamrick \& Godt, 1990).

Trabalhos revisados de 653 estudos de aloenzimas em plantas, por Hamrick \& Godt (1990), demonstraram que as plantas apresentam em média $50,5 \%$ dos locos polimórficos, heterozigosidade média esperada de 0,149 e número de alelos por locos de 1,96. A diversidade genética é de aproximadamente 0,11 e a divergência média $\left(\mathrm{G}_{\mathrm{ST}}\right)$ de $20 \%$ entre populações. Dentro das amplas condições diferenciadas nas espécies, os autores ressaltaram que os fatores que mais contribuiram para a variação dos dados foram a distribuição geográfica e o sistema reprodutivo. 
No estudo da variação genética de B. excelsa, Buckley et al. (1988), esses autores encontraram uma taxa de heterozigose de 0.19 , com $54.3 \%$ dos locos amostrados sendo polimórficos. Os autores citados observaram que a população estudada encontrava-se com os genótipos dentro da expectativa de Hardy-Weinberg para os sistemas $\mathrm{Fest}_{2}$ e $\mathrm{Pgm}_{2}$ ( $\mathrm{F}=0.405$ e 0.443 , respectivamente). Encontraram também, usando o coeficiente de Nei, uma divergência gênica entre populações de apenas 3,75\%, verificando uma maior diversidade dentro das populações.

\subsection{Sistema Reprodutivo}

O sistema reprodutivo das espécies de florestas tropicais era idealizado como sendo autógamo, antes dos primeiros estudos, por se acreditar na dificuldade de locomoção de pólen. Em 1974, Bawa estudou na Costa Rica o sistema reprodutivo de várias espécies arbóreas tropicais, e descobriu que as espécies possuiam mecanismos que favoreciam a fecundação cruzada. Observou que das 34 espécies estudadas, 27 apresentavam auto-incompatibilidade e que apenas sete eram auto-compativeis.

Os sistemas reprodutivos determinam o modo de transmissão de genes de uma geração a outra, e sua mudança genética está ligada direta ou indiretamente com o processo de acasalamento (Brown, 1990 e Clegg, 1980) determinando os niveis de diversidade genética e a distribuição da variabilidade entre e dentro de populações (Hamrick et al., 1979; Hamrick \& Godt, 1990).

\subsubsection{Sistema De Cruzamento}

O processo de acasalamento aliado a mecanismos fisiológicos e morfológicos controla o grau de alogamia e autogamia em plantas superiores e pode envolver desde dioicismo e auto-incompatibilidade até o hermafroditismo com autofecundação predominante (Grant, 1958 citado por Aguiar-Perecin, 1984).

Em espécies autógamas, diversos são os fatores que podem ter contribuído para seu sucesso, induzindo-as a produzir variabilidade suficiente para sobreviver a variações ambientais (Aguiar-Perecin, 1984). A autogamia pode ser sensu strictu - fecundação pelo grão de pólen da mesma flor, geitonogâmica - fecundação com flor da mesma planta ou por cleistogamia - fecundação antes da abertura da flor. 
As plantas alógamas utilizam-se da xenogamia, fecundação cruzada, como mecanismo para assegurar sua variabilidade. Esses mecanismos podem ser diversos, como (Richards, 1986 e Dafni, 1992):

- Dioicismo - separação do sexo na flor;

- Dicogamia - amadurecimento dos órgãos em épocas diferentes;

- Heterostilia - como barreira espacial, produzindo flores de dois ou mais tipos com comprimento de estiletes e estames variáveis;

- Hercogamia - dispositivos especiais como barreiras físicas; e

- Auto-incompatibilidade (SI) - recombinação bioquímica, resultando em autoincompatibilidade gametofitica e auto-compatibilidade esporofitica.

O sistema reprodutivo de muitas espécies arbóreas e arbustivas é caracterizado por auto-incompatibilidade (Bulock, 1985 e Bawa et al., 1985) e é controlado em muitas espécies hermafroditas por caracteres do alelismo múltiplo, denominado pela série alélica $S$ (self-incompatibility) conhecida como incompatibilidade gametofítica e esporofitica (Richards, 1986; Futuyma, 1992 e Ramalho, et al., 1995).

Ramalho et al. (1995) citam que aproximadamente metade das familias de Angiospermas hermafroditas, representada por mais de 3.000 espécies, apresenta o fenômeno de alelismo múltiplo, dentre elas, a macieira, repolho, brócolis, crotalária, cacau e maracujá.

Estudos detectaram a presença de uma glicoproteína no estigma de flores em espécies com incompatibilidade tanto gametofítica como esporofítica, sendo que cada alelo da série produz uma glicoproteína específica. Esta só é produzida nos tecidos da flor feminina, onde o pólen e tubo polínico entram em contato. Uma pequena quantidade de glicoproteína foi constatada no ovário, acreditando que seja para assegurar a incompatibilidade. A incompatibilidade gametofítica é considerada mais eficiente do que a esporofítica, por não permitir a formação de descendentes homozigotos e provavelmente seja esta a causa de ser a mais difundida (Ramalho et al., 1995).

Estudos na América Central revelaram que 65\% das espécies de árvores tropicais são hermafroditas, $11 \%$ são monóicas e $23 \%$ dióicas. Dentre esses grupos, o sistema de cruzamento predominante é a fecundação cruzada, em função de serem autoincompativeis ou dióicas (Bawa, 1992). 
A taxa de cruzamento de uma espécie pode ser quantificada através do uso de marcadores genéticos. Essa quantificação utiliza a estimação do parâmetro $t$ de Clegg (1980), que pode variar de zero (altos niveis de parentesco ou autofecundação - endogamia) a um (fecundação totalmente cruzada - alógama) (Bawa, 1992).

Alta taxa de cruzamento têm sido encontrada em estudos sobre o sistema de cruzamento de espécies arbóreas tropicais (Tabela 2). No grupo de espécies analisadas por Bawa (1992) apenas Cavanillesia platanifolia apresentou sistema de cruzamento misto, com taxas de $0,57,0,35,0,21$ e 0,66 nos anos $1987,1988,1989$ e 1990, respectivamente.

Tabela 2. Dados da taxa de cruzamento em árvores tropicais.

\begin{tabular}{lcl}
\hline \multicolumn{1}{c}{ Espécies } & $\hat{t}_{\mathrm{m}}(\mathrm{SE})$ & \multicolumn{1}{c}{ Autor (es) } \\
\hline Beilschmedia pendula & $0,918(0,058)$ & Murawski et al. 1991 \\
Bertholletia excelsa & $0,849(0,033)$ & O'Malley et al. 1988 \\
Brosimum alicastrum & $0,875(0,035)$ & Murawski et al. 1991 \\
Carapa guianensis & $0,967(0,022)^{1}$ & Hall et al. 1994 \\
& $0,986(0,028)^{2}$ & Hall et al. 1994 \\
Carapa procera & 0,84 & Doligez \& Joly 1997 \\
Ceiba pentrandra & $0,689(0,032)$ & Murawski \& Hamrick 1992 \\
Cordia alliodora & 0,966 & Boshier et al. 1995 \\
Couratari multiflora & $0,953(0,040)$ & Lepsch-Cunha 1996 \\
Pithecellobium pedicellare & $0,951(0,022)$ & O'Malley \& Bawa 1987 \\
Platypodium elegans & $0,924(0,043)^{3}$ & Murawski \& Hamrick 1991 \\
& $0,898(0,043)^{4}$ & Murawski \& Hamrick 1991 \\
Psychotria faxlucens & 0,995 & Pérez-Nasser et al. 1993 \\
Quararibea asterolepis & $1,008(0,045)$ & Murawski et al. 1990 \\
Tachigalia versicolor & $0,937(0,044)$ & Murawski \& Hamrick 1991 \\
Trichilia tuberculata & $1,007(0,028)$ & Murawski \& Hamrick 1991 \\
\hline Fonte: Bawa (1992). & \multicolumn{2}{c}{${ }^{2}$ para Gerardo Fallas. ${ }^{3}$ Trabalho realizado em 1988 e ${ }^{4}$ em 1989. }
\end{tabular}

Como observa-se na Tabela 2, O'Malley et al. (1988) encontrou alta taxa de cruzamento para populações naturais de $B$. excelsa, sugerindo que a espécie é preferencialmente de fecundação cruzada. A estimativa obtida para $B$. excelsa está dentro do encontrado para as demais espécies arbóreas apresentadas na Tabela 2. 


\subsubsection{Fluxo Gênico}

Do ponto de vista animal, a polinização é um resultado secundário da colheita de pólen, néctar, essências e peças florais, que são fornecidos nas flores. Do ponto de vista da planta, a polinização é uma maneira de aumentar ao máximo o fluxo de genes às outras flores e a recepção de genes de outras plantas (Janzen, 1980). O fluxo de pólen é um importante componente do fluxo gênico, representando, entretanto apenas uma fração do fluxo gênico entre pais e sua descendência (Govindaraju, 1988a).

Fluxo gênico, por definição, inclui movimentos de gametas, sementes, individuos ou grupos de indivíduos, e a recolonização de populações inteiras (Slatkin, 1981), pode-se dizer que é a entrada ou saída recorrente de genes de uma população por migração.

A movimentação de alelos entre e dentro de populações naturais é resultado do processo de dispersão dos propágulos, bem como dos efeitos da seleção natural associados à dinâmica demográfica (Reis, 1996). Dentro desse contexto, Kageyama (1986) ressalta que a dispersão de pólen e sementes são componentes que determinam o fluxo gênico entre e dentro de populações influenciando diretamente, segundo Martins (1987), a estrutura genética das populações. Esse último autor considera que o fluxo de genes, tanto entre como dentro da população, está diretamente ligado ao seu sistema reprodutivo.

O fluxo gênico é um fator altamente relevante para a estrutura genética, pois têm o efeito de homogeneizar a composição genética (Futuyma, 1992), contribuindo como elo atenuador na divergência entre populações. Segundo Wright (1931), o fluxo gênico, ou seja, o número de migrantes por geração ( $\mathrm{Nm}$ ) deve ser maior que 1 (um) para evitar a divergência genética por deriva entre populações locais; caso o Nm seja menor que 1 (um), estas populações estarão mais sujeitas a divergência.

O fluxo gênico pode ser estimado por medidas diretas ou indiretas. As medidas diretas estimam as distâncias de dispersão e o sucesso no estabelecimento das diásporas, visando inferir a magnitude do fluxo gênico no espaço de tempo. As medidas indiretas utilizam as frequências alélicas ou as diferenças em seqüência de DNA para estima-lo. Medidas indiretas medem fluxo gênico histórico armazenados nas populações,e refletem a migração que deve ter ocorrido no passado para gerar as divergências gênicas observadas atualmente (Barton \& Slatkin, 1986 e Perecin, 2000). 
Govindaraju (1988b) revisando diversos trabalhos analisou o fluxo gênico de 115 espécies e subespécies de plantas representando diversos gêneros, histórico de vida e condições ecológicas de espécies de clima temperado e tropical. Destas, verificou que 41 são polinizadas por animais, 40 por vento e 34 de auto-polinização. Subdividindo o fluxo gênico em níveis de amplitude alto, médio e baixo, o autor encontrou que as espécies polinizadas por animais apresentam fluxo gênico menor do que aquelas polinizadas pelo vento (alto) e, maior do que aquelas resultantes de autopolinização (baixo). Os níveis médios de fluxo gênico em espécies auto-polinizadas, polinizadas por animais e vento foram $0,8,1,2$ e 2,9 , respectivamente.

Resultados similares foram encontrados por Hamrick (1987), onde o fluxo gênico variou de $0,082-0,477$ para espécies de auto-polinização, 0,050-0,757 sistema misto de cruzamento, 0,244 - 13,90 animais, e 5,3 - 37,8 para aquelas polinizadas por vento.

A polinização de $B$. excelsa é efetuada por abelhas de grande porte (Tabela 1) e estas possuem capacidade de locomoção a grandes distâncias. A dispersão de semente da espécie é efetuada, principalmente, por Dasyprocta $s p$ em um raio de $5 \mathrm{Km}$. Assim, apesar da dispersão de sementes ser de média distância, espera-se encontrar valores de fluxo gênico para as subpopulações estudadas dentro ou acima do estabelecido para espécies polinizadas por animais. Presume isso em função do eficiente mecanismo de polinização entre populações da espécie que resulta em baixo índice de divergência.

\subsection{Eletroforese De Isoenzimas}

Diversos métodos têm sido utilizados no estudo da variação genética entre indivíduos e populações. Dentre eles, a eletroforese de isoenzimas têm se destacado por permitir maior rapidez na produção dos dados genéticos e apresentar baixo custo na sua aplicação (Kageyama, 1990).

As proteínas enzimáticas são altamente informativas do ponto de vista genético por serem a expressão do produto primário dos genes e contribuem sobremaneira para estudos de caracterização, sistemática e evolução. As isoenzimas são diferentes formas moleculares de uma enzima, catalisando a mesma reação na célula e com afinidade para um mesmo substrato. Podem ser controladas por um ou vários alelos situados num mesmo loco, ou em diferentes locos (Alfenas et al., 1991). Quando as 
enzimas são controladas por alelos de um único loco, elas são denominadas de aloenzimas (Robinson, 1998).

Com a eletroforese em gel, tornou-se possivel a codificação dos locos de proteinas, especialmente as enzimas, possibilitando a contagem do número de locos com variação, verificar o números de alelos e distinguir homozigotos e heterozigotos (Futuyma, 1992).

A eletroforese de isoenzimas é uma técnica relativamente simples, rápida e de alto valor informativo, permitindo vários locos enzimáticos serem revelados em uma única corrida eletroforética, através do fatiamento do gel. Essa técnica tem sido utilizada em estudos de taxonomia, fisiologia, bem como genética de plantas, animais e microorganismos (Alfenas et al. 1991). Milhares de pesquisadores utiliza essa técnica em suas pesquisas, revolucionando muitos campos de estudo (May, 1992). Dentre esses estudos podemos citar várias linhas de pesquisas com espécie vegetais: estimativas da variabilidade genética, consequências evolutivas, diferenciação geográfica de populações dentro de espécies, parâmetros que descrevem o sistema de cruzamento, fluxo gênico, recursos genéticos in situ, melhoramento e outros (Robinson, 1998). 


\section{MATERIAIS E MÉTODOS}

\subsection{Local do Estudo}

Este trabalho foi realizado na fazenda Bahia, que se localiza no Ramal do Cachoeira entre a BR 317 e o Projeto de Assentamento Agroextrativista Cachoeira, próximo à cidade de Xapuri a $10^{\circ} 40^{\prime} \mathrm{S}$ e $68^{\circ} 30^{\prime} \mathrm{W}$, no Estado do Acre (Figura 3).

A floresta na região do estudo é caracterizada como Floresta Tropical Densa, por apresentar vegetação heterogênea e sub-bosque formado por denso extrato de porte arbustivo, onde são encontrados aberturas com palmeiras (Fundação Tecnológica do Estado do Acre, 1990 e Acre, 1991).

Para este estudo, em Janeiro de 1999, foram analisadas três áreas com ocorrência de B. excelsa: Floresta natural e duas áreas de pastagens, sendo uma pastagem com 2 anos (P2) de formação, e a outra pastagem com 4 anos (P4). Essas três áreas ainda eram mata contínua em 1994, que sofreu fragmentação em 1995 e 1997 para formação das pastagens. Por força da lei 4771 , as árvores de $B$. excelsa que encontravamse nessa área não puderam ser retirados, resultando nos remanescentes da espécie em pastagens isolados completamente da áreas de floresta. Segundo o proprietário da fazenda, tanto a pastagem de 2 anos quanto a de 4 anos sofreram queimadas apenas por dois anos consecutivos, originadas de fogo na circunvizinhança. A distância entre a floresta primária e a pastagem de 2 anos é de aproximadamente $1000 \mathrm{~m}$ a $3000 \mathrm{~m}$ dependendo da localização na área de pastagem em relação a floresta. Entre a floresta primária e a pastagem de 4 anos é cerca de $300 \mathrm{~m}$ a $1500 \mathrm{~m}$, já a distancia entre as duas idades de pastagens a extensao pode variar de $100 \mathrm{~m}$ e extender por mais de $2.000 \mathrm{~m}$.

Como a definição de população é bastante complexa consideramos que as amostras coletadas em áreas adjacentes, para este estudo, eram subpopulações. 


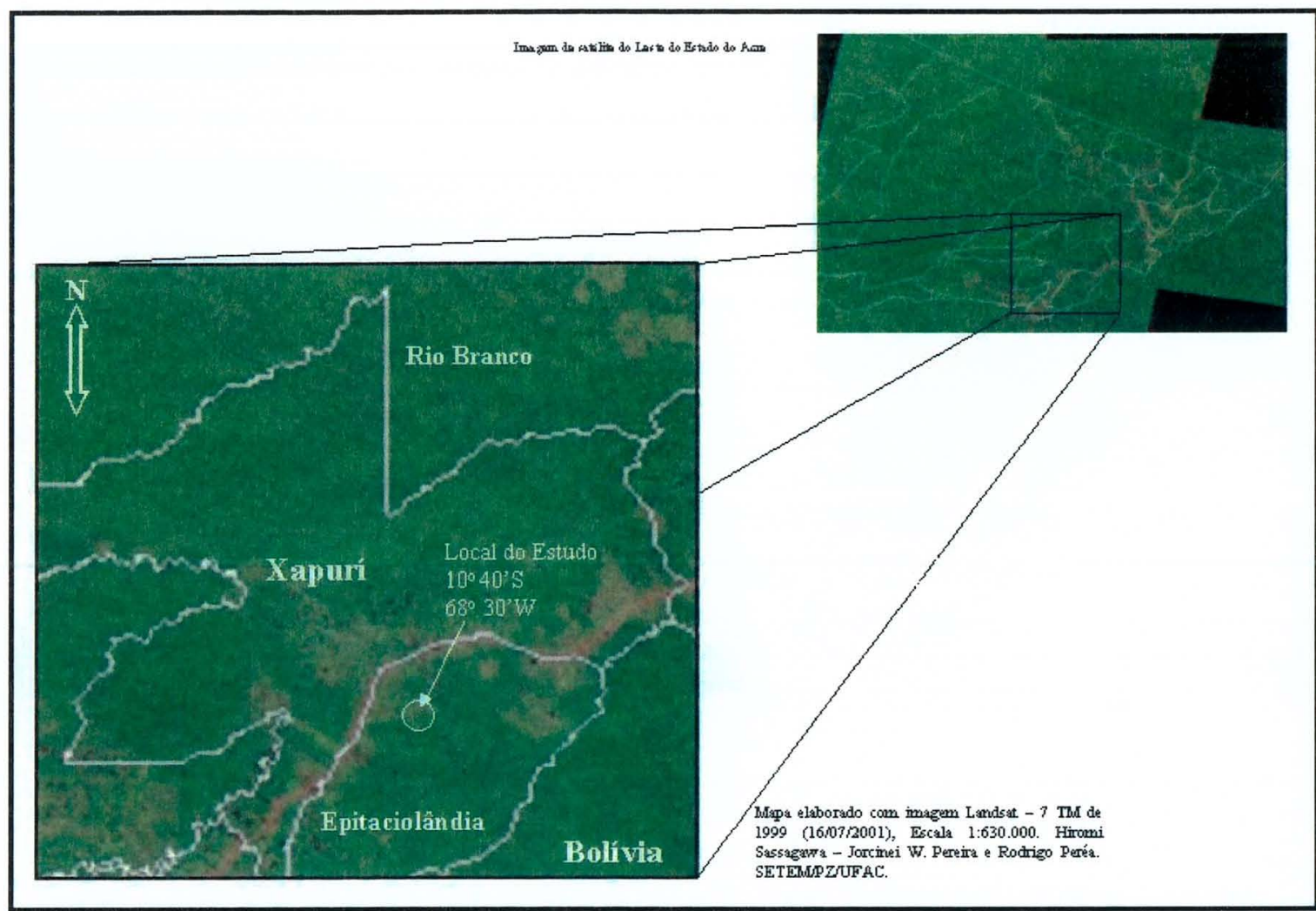

Figura 3 - Imagem da região leste do Estado do Acre, onde foi realizado o estudo da estrutura genética nas subpopulações de Castanha do Brasil (Bertholletia excelsa) em floresta e em pastagens com 2 e 4 anos de formação..

\subsection{Clima}

O clima de Xapuri é caracterizado como quente, atingindo temperatura média de $26^{\circ} \mathrm{C}\left(10^{\circ} \mathrm{C}\right.$ a $\left.38^{\circ} \mathrm{C}\right)$, e úmido, com índice pluviométrico superior a $1.800 \mathrm{~mm}$ (150mm a 1.900mm) (Fundação Tecnológica do Estado do Acre, 1990). A umidade relativa para o Estado do Acre é elevada, com médias em torno de 80 - 90\% durante todo o ano, sem muitas oscilações (Deus et al., 1982).

\subsection{Coleta de Campo}

Foram selecionadas, plaqueteadas e coletadas folhas de 30 árvores adultas (matriz) de cada subpopulação de Bertholletia excelsa, totalizando 90 árvores. A escolha das matrizes foi tomada pelo vizinho mais próximo, seguindo o modelo adotado pelo "Castanheiro" quando faz a busca e mapeamento para construção da trilha de Castanha do Brasil. A direção de árvore a árvore foi tomada com uma bússola; a distância 
entre árvores e altura das mesmas foram estimadas pelo mateiro (Nilson T. Mendes) e o CAP medido com o auxílio de trena. Algumas características de sanidade e exudação de resina foram anotadas.

As folhas foram devidamente identificadas e acondicionadas em sacos plásticos em ambiente refrigerado para preservação das enzimas e transportadas até o Laboratório de Reprodução e Genética de Espécies Arbóreas (LARGEA/LCF/ESALQ/USP).

Dentre as 30 árvores matrizes de cada subpopulação, as primeiras 10 árvores que estavam com frutos foram selecionadas para obtenção das progênies. Destas, tomou-se ao acaso 20 ouriços cada, que foram abertos pelo mateiro com auxílio do facão. Por ouriço tomou-se ao acaso 10 sementes, obtendo-se em média 2.000 sementes por subpopulação.

Visando acelerar o período de germinação das sementes, mulheres quebradeiras de castanha retiraram o tegumento da semente, parte lenhosa, com o auxilio de prensa de mesa, seguindo a metodologia de Muller (1982; 1995). No processo de retirada do tegumento, muitas amêndoas foram danificadas, mas conseguiu-se obter em média 3 amêndoas por ouriço, aproximadamente 600 amêndoas por subpopulação para o plantio. Para transporte das amêndoas até o LARGEA, utilizou-se isopor com vermiculita umedecida de forma a manter o teor de umidade.

\subsection{Viveiro: Plantio das Sementes para Obtenção de Progênies}

As amêndoas de $B$. excelsa foram plantadas em sacos plásticos em substrato por vermiculita e areia, e acondicionadas na estufa do viveiro de mudas do Departamento de Ciências Florestais da Escola Superior de Agricultura "Luiz de Queiroz" (ESALQ/USP), sob sombrite a $40 \%$. O plantio das amêndoas seguiu instruções de Muller (1991) e do mateiro Nilson T. Mendes. Cada indivíduo foi identificado com plaquetas de alumínio grampeadas no saco plástico, segundo identificação estabelecida para árvores matrizes em campo.

Um ano após o plantio, foram selecionadas em média 15 mudas por progênie de cada subpopulação, totalizando 450 individuos. A escolha se deu uma muda por ouriço com altura superior a $7 \mathrm{~cm}$ e na seqüência de ordenação. Uma folha de cada muda era coletada para extração das enzimas. 


\subsection{Desenvolvimento de Protocolo para Eletroforese de Isoenzima de Bertholletia excelsa}

As análises de eletroforese de isoenzimas foram realizadas utilizando os tecidos foliares coletados das árvores matrizes e das progênies obtidas a partir de plantio em estufa.

Para extração das enzimas, utilizou-se aproximadamente $20 \mathrm{mg}$ de tecido foliar, dois mg de PVP-P e PVP $360,0,15 \mathrm{ml}$ de solução extratora (anexo) e areia lavada. A maceração se procedeu em placas de porcelana e cadinhos resfriados, após o qual os wicks (papel whatman $n^{\circ} 3$ ) eram embebidos no extrato macerado e guardados em eppendorfs numerados e acondicionados em freezer $\mathrm{a}-80^{\circ} \mathrm{C}$.

Foram testados seis sistemas tampão cuba/gel, segundo Alfenas (1991) e Hillis (1996): Citrato morfolina (CM), Tris Borato - EDTA, Histidina, Tris Citrato, Tris Citrato Borato e Litium Borato, e 29 sistemas isoenzimáticos (anexo 1)

Os dados de freqüência gênica, utilizados nas análises, foram obtidos a partir da interpretação de zimogramas resultantes da eletroforese de isoenzimas em gel horizontal de penetrose de milho, mantidos em refrigerador a $4^{\circ} \mathrm{C}$.

Os géis de amido eram feitos no dia anterior ao da corrida e acondicionados em geladeira. No dia seguinte, as amostras eram descongeladas e aplicadas no gel, sendo removida após 30 minutos de corrida. O sistema Citrato Morfolina iniciava a corrida com $35 \mathrm{~mA}$, perfazendo um total de 8 horas, o EDTA iniciava a corrida com $75 \mathrm{~mA}$ e com a mesma duração. Completada essa etapa, o géis eram fatiados com fio de nylon em 6 fatias e colocados em pirex para coloração. As etapas subseqüentes eram o aquecimento em estufa, limpeza dos géis, interpretação e esquematização dos zimogramas e, fixação dos mesmos em glicerina para posterior transparentização (Alfenas, 1991).

\subsection{Análises estatísticas}

\subsubsection{Variabilidade Genética}

Utilizou-se o programa BIOSYS-2 (Swofford \& Selander, 1989) para obter as estimativas das frequências alélicas e os niveis de diversidade (heterozigosidade média observada e esperada por loco, número médio de alelos por loco $(\hat{A})$ e porcentagem de 
locos polimórficos $(\hat{P}))$ e estimar o coeficiente de endogamia $F$ de Wrigth $(1965,1978)$ por loco e para subpopulações. Os dados utilizados para os cálculos foram de matrizes e progênies.

As frequências alélicas foram estimadas contando-se o número de vezes que um alelo é encontrado em cada subpopulação, dividindo-se pelo número total de genes da subpopulação:

$$
\hat{p}_{\mathrm{i}}=\mathrm{n}_{\mathrm{ij}} / \mathrm{n}_{\mathrm{j}}
$$

onde: $\hat{p}_{\mathrm{i}}=$ frequência do alelo $\mathrm{i}$ na população $\mathrm{j}$,

$$
\begin{aligned}
& n_{i j}=\text { número de ocorrências do alelo i na população j, e } \\
& n_{j}=\text { número total de alelos na população j. }
\end{aligned}
$$

A porcentagem de locos polimórficos $(\hat{P})$ foi obtida através da divisão do número de locos polimórficos pelo número total de locos analisados. Considerou-se loco polimórfico aquele cuja frequencia do alelo mais comum não exceder 0,99 .

O número médio de alelo por loco $(\hat{A})$ foi obtido pela somatória de todos os alelos observados dividida pelo número total de locos.

A heterozigosidade esperada ou diversidade gênica $\left(\hat{H}_{\mathrm{e}}\right)$, foi obtida através de:

$$
\hat{H}_{\mathrm{e}}=1-\sum \mathrm{p}_{\mathrm{i}}{ }^{2}
$$

onde: $\hat{p}_{\mathrm{i}}=$ frequência do alelo $\mathrm{i}$.

A heterozigosidade observada $\left(\hat{H}_{\mathrm{o}}\right)$ é a proporção do número total de heterozigotos em relação ao número total de indivíduos, sendo obtida através da expressão:

$$
\hat{H}_{\mathrm{o}}=1-\sum \mathrm{p}_{\mathrm{ii}}
$$

onde: $\hat{p}_{\mathrm{ii}}=$ frequência de individuos homozigotos para o alelo $\mathrm{i}$.

O coeficiente de endogamia ou índice de fixação $\left(\hat{F}_{\text {is }}\right)$ de Wrigth (1965) é definido como o total de heterozigosidade observada em relação à esperada em cruzamentos ao acaso: 


$$
\hat{F}_{\text {IS }}=\frac{\hat{H} e-\hat{H} o}{\hat{H} e}
$$

\subsubsection{Estrutura Genética}

Utilizou-se o programa Genetic Data Analysis - GDA versão 1 (Lewis \& Zaykin, 1999) para calcular a variância das frequências alélicas, sendo assim possivel estimar o coeficiente de coancestralidade $(\theta)$ de Cockerham (Cockerham, 1969 e Vencovsky, 1992). Esta metodologia possibilita a avaliação da divergência em diferentes niveis de hierarquia, bem como, calcular as estimativas com correção para tamanho de população finita. Para estas análise foram utilizados dados dos indivíduos adultos e de progênies.

A análise estatística dos dados, a princípio, agrupou as três subpopulações. Posteriormente uma nova análise foi realizada tomando as subpopulações duas a duas, com o objetivo de observar as divergências entre cada par de subpopulação. É importante ressaltar que para essa análise foram utilizados todos os locos monomórficos e polimórficos, no intuito de se obter uma amostra totalmente ao acaso.

O modelo matemático utilizado para essa análise foi:

$$
Y_{i j k l}=\mu+p_{i}+f_{j(i)}+a_{k(i j)}+g_{l(j k)}
$$

onde: $\quad Y_{\mathrm{ijkl}}=$ frequência do alelo $\mathrm{k}$ no indivíduos $\mathrm{j}$, da família $\mathrm{i}$, da subpopulação $\mathrm{I}$

$$
\begin{aligned}
& \mu=\text { média geral } \\
& \mathrm{p}_{\mathrm{i}}=\text { efeito da subpopulação } \mathrm{I} ; \mathrm{I}=1,2, \ldots \ldots \ldots, \mathrm{a} \\
& f_{j(i)}=\text { efeito da familia i dentro da subpopulação } l ; i=1,2, \ldots ., b_{i} \\
& a_{k(i j)}=\text { efeito do indivíduo } \mathrm{j} \text {, dentro da família } \mathrm{i} \text {, dentro da população } \mathrm{l} ; \mathrm{j}= \\
& 1,2, \ldots, c_{i j} \\
& \mathrm{~g}_{((\mathrm{ijk})}=\text { efeito do gene } \mathrm{k} \text {, dentro da do indivíduo } \mathrm{j} \text {, dentro da família } \mathrm{i} \text {, dentro } \\
& \text { da subpopulação } 1 ; k=1,2, \ldots, n_{i j k} \text {. } \\
& \text { Conforme Cockerham (1969) e Vencovsky (1992), esse modelo }
\end{aligned}
$$
matemático gera componentes que podem ser definidos em termos de correlações 
intraclasse ou coeficientes de coancestralidade em diferentes niveis de hierarquia. Os coeficientes de coancestralidade foram obtidos através dos componentes de variância.

Segundo os autores supracitados, através da frequência de um gene em um determinado loco, pode-se estimar:

i) a média da distância genética entre as subpopulações ou correlação entre frequências alélicas das plantas de diferentes famílias da mesma subpopulação $\left(\theta_{p}\right)$;

ii) coeficiente de parentesco ou coancestralidade das plantas dentro das familias ou correlação entre frequências alélicas de plantas da mesma familia $\left(\theta_{\mathrm{F}}\right) ; \mathrm{e}$

iii) correlação entre alelos de plantas diferentes subpopulações ou coeficiente de cruzamento de Wright.

\subsubsection{Taxa De Cruzamento:}

A estimativa do sistema de cruzamento foi feita com base nas freqüências gênicas obtidas da análise isoenzimática, usando o programa MLTR - Multilocus Mating System Program (Ritland, 1997), por ser um modelo de cruzamento misto. Esse programa obtém valores de taxas de fecundação cruzada para cada loco individual e uma média das estimativas para a população $\left(t_{s}\right)$; taxa de fecundação cruzada com base em locos múltiplos a nível de população $\left(t_{m}\right)$; e freqüências alélicas de pólen e óvulos com base nos locos individuais para obter o coeficiente de endogamia (f) de Wright.

Esse programa pressupõe que:

i) todos genótipos maternais tem a mesma probabilidade de acasalamento a partir de um conjunto polínico homogêneo;

ii) os alelos dos diferentes locos segregam independente;

iii) cada alelo está em equilibrio de Hardy-Weinberg;

iv) os marcadores genéticos não são afetados por seleção ou mutação durante o tempo de reprodução e de amostragem das progênies.

Foram utilizados nesta análise quatro locos polimórficos, dos quais foram obtidas as frequências genotípicas das familias analisadas em cada subpopulação. A estimativa do erro padrão da $t_{m}$ de cada subpopulação foi realizada através de "boostrap", 
que é uma unidade de reamostragem. Utilizou-se 1.000 reamostragens dentro das famílias para cada subpopulação, conforme Murawski et al. (1994).

Diferenças positivas entre $\hat{t}_{\mathrm{m}}$ e $\hat{t}_{\mathrm{s}}\left(\hat{t}_{\mathrm{m}}-\hat{t}_{\mathrm{s}}\right)$ indicam ocorrência de acasalamento entre aparentados e entre $\hat{t}_{\mathrm{m}}$ e $1,0\left(\hat{t}_{\mathrm{m}}-1,0\right)$ indicam a proporção de autofecundação $(s$ ) ocorrida no último evento reprodutivo (Ritland, 1990).

\subsubsection{Fluxo Gênico:}

A medida do fluxo gênico foi feita mediante abordagem indireta, segundo a metodologia proposta por Wrigth (1931), a qual avalia a quantidade de alelos migrantes $(\mathrm{Nm})$ e a divergência genética entre populações $\left(F_{\mathrm{ST}}\right)$ :

$$
N m=\frac{1}{4 \alpha}\left[\frac{1}{F_{s t}}-1\right]
$$

Onde: $\mathrm{N}=$ número de indivíduos migrantes da subpopulação, $\mathrm{e}$

$$
m=\text { taxa de migração }
$$$$
F_{S T}=\text { é a divergência genética entre subpopulações }
$$

$$
\alpha=\left[\frac{n}{n-1}\right]^{2} \text { onde: } \mathrm{n}=\text { número de subpopulações }
$$

Segundo Cockerhmam e Weir (1993), o emprego de $\hat{\theta} \rho$ como estimador da divergência genética é mais adequada que $\hat{F}_{\mathrm{ST}}$. Partindo desse pressuposto, para o cálculo de $\hat{N} m$ utilizou-se o $\hat{\theta} \rho$ nessa análise como estimador do fluxo gênico.

O fluxo gênico foi estimado com os dados das 30 progênies das subpopulações: floresta, pastagem de 2 anos e de 4 anos.

\subsubsection{Tamanho Efetivo ( $\mathrm{Ne})$}

O tamanho efetivo pode ser entendido como sendo a medida da representatividade genética contida em uma amostra em relação à geração anterior (Vencovsky, 1987). Essa medida visa compreender a viabilidade a longo prazo de 
populações, desse modo, a preocupação é estabelecer um tamanho mínimo viável de uma população (Kageyama \& Lepsch-Cunha, 2001).

Assim, para a estimativa do tamanho efetivo aplicou-se a metodologia de Li (1976) para árvores matrizes e a de Vencovsky (1992) para as progênies, a partir dos componentes de variância das freqüências alélicas:

Para os indivíduos adultos utilizou-se a seguinte equação:

$$
\hat{N}_{\mathrm{e}}=\mathrm{n} /(1+\hat{f})
$$

onde: $n=$ número total de individuos na subpopulação; e

$$
\hat{f}=\text { coeficiente de endogamia na subpopulação. }
$$

A estimativa do $N_{e}$ para o conjunto de populações foi obtido pela soma $\operatorname{dos} N_{e}$ (s) individuais de cada subpopulações.

Para o cálculo do tamanho efetivo de cada subpopulação de progênies, utilizou-se a medida de $N_{e}$ proposta por Vencovsky (1992), por meio da variância total $\left(\sigma_{T}^{2}\right)$ e a variância média total $\left(\bar{\sigma}_{T}^{2}\right)$ :

$$
\begin{array}{ll}
\hat{\bar{\sigma}}_{T}^{2}=\frac{\hat{\sigma}_{T}^{2}}{2 \hat{N} e} \quad \text { ou } & \hat{N} e=\frac{\hat{\sigma}_{T}^{2}}{2 \hat{\sigma}_{T}^{2}}, \text { sendo: } \\
\hat{\sigma}_{T}^{2}=\hat{\sigma}_{P}^{2}+\hat{\sigma}_{F}^{2}+\hat{\sigma}_{I}^{2}+\hat{\sigma}_{G}^{2}=\mathrm{p}(1-\mathrm{p}), & \mathrm{e} \\
\hat{\bar{\sigma}}_{T}^{2}=\frac{\hat{\sigma}_{P}^{2}}{r}+\frac{\hat{\sigma}_{F}^{2}}{f}+\frac{\hat{\sigma}_{I}^{2}}{i}+\frac{\hat{\sigma}_{G}^{2}}{2 i}, &
\end{array}
$$

onde: $r=$ número de subpopulações;

$f=$ número total de progênies; $e$

$\mathrm{i}=$ número total de plantas.

Para os cálculos das três subpopulações, utilizou-se os dados de variância conjunta das três subpopulações. 


\section{RESULtADOS E DISCUSSÃo}

\subsection{Sistema Isoenzimático}

A partir de nove sistemas isoenzimáticos analisou-se 90 indivíduos adultos e 30 famílias de polinização aberta oriundas de sementes coletadas em 10 famílias de cada subpopulação amostrada.

Os zimogramas da espécie (esquema do padrão encontrado para cada enzima nos géis de amido) basearam-se em 13 locos e 19 alelos (Figura 4). Para a interpretação dos locos enzimáticos, padronizou-se a leitura determinando que o loco que controla a enzima à maior migração em relação ao ponto de origem (catodo) foi denominado de loco 1 . O loco que migrou um pouco menos em relação ao ponto de origem foi denominado de loco 2.

Para a indentificação dos alelos adotou-se o mesmo sistema de interpretação dos locos, considerou-se a distância em que as bandas se posicionavam em relação ao alelo 1 , e denominou-se de alelo 1,2 ... e assim sucessivamente.

O padrão isoenzimático apresentado pela espécie, neste trabalho, apresentou-se de forma simples para a interpretação das enzimas: SK, LAP, 6PGDH, G6PDH, e Fest-1, por serem locos monomórficos; e Est-1, Dia-2 e PO por serem enzimas monoméricas com dois alelos cada. O mesmo fato não ocorreu para o sistema MDH e Fest-2, pois tiveram sobreposição de locos e alelos.

\section{Malato Desidrogenase (MDH)}

Este sistema Isoenzimático apresentou 2 locos diméricos. Entretanto, o loco que mais migrou (loco 1) sobrepôs seu alelo 2 ao alelo 1 do loco dois (Figura 4). Um outro fato ocorrido foi que o loco1 não apresentou a banda intermediária entre seus dois alelos. Nas matrizes a separação dos locos e alelos se deu de forma mais nitida e definida quando comparada com os das progênies. Esse fato pode ser decorrente do tipo de enzima que as plântulas apresentaram no periodo de extração, por serem ainda muito jovens (em media 10 meses a 1 ano do plantio), ou em função do tampão de extração. $O$ 
tampão de extração utilizado para as plântulas foi o mesmo testado para as matrizes. Todavia, pode ser que as enzimas se degradem mais rapidamente em plântulas muito jovens da espécie.

\section{Esterase colorimetrica (EST)}

Esse sistema apresentou três locos. Destes, dois não apresentaram boa resolução para serem interpretados. O loco interpretado foi a Est-1, apresentando um padrão monomérico com dois alelos (Figura 4).

\section{Esterase Fluorescente (FEST)}

A FEST apresentou ótima resolução para seus três locos, sendo um monomórfico (Fest-1) e dois diméricos com dois alelos cada (Fest-2 e Fest-3). Entretanto, os dois locos diméricos estavam totalmente sobrepostos, dificultando a interpretação e conseqüentemente a análise estatistica dos dados. Sobreposição semelhante aos locos Fest-2 e Fest-3 encontrados nesse trabalho para a espécie é apresentado por May (1992) para enzima dimérica com dois alelos, que segundo o autor torna inviável a aplicação das análises estatísticas para este caso. Assim, esses dois locos (Fest-2 e Fest-3) apesar de apresentaram boa resolução, não tiveram como serem interpretados.

\section{Peroxidase (PRX)}

Esse sistema apresentou um total de quatro locos; destes, a Prx-1 e Prx-2 foram monomórficos e Prx-2 e Prx-3 foram monoméricos com dois alelos cada. A migração dos três primeiros locos ocorreu do ponto de origem em sentido ao pólo anodo (positivo) e o quarto loco (Prx-4) migrou da origem para o pólo catodo (negativo) (Figura 4).

Matrizes: do total de indivíduos analisados (90) nas três subpopulações, apenas uma árvore da subpopulação floresta apresentou o alelo 2 no loco Prx-3, demonstrando ser um alelo raro. Infelizmente, não foi possivel a coleta de frutos dessa árvore por não ter apresentado frutificação.

Em alguns indivíduos observou-se a ausência de alelos nos locos Prx-2 e Prx-3, embora fossem presentes concomitantemente em Prx-1 e Prx-4. 
Progênies: o padrão enzimático apresentado pelas progênies para as três subpopulações foi diferente do das matrizes. Os locos 1 e 2 não estão em atividade nas progênies, pelos menos nesse tempo de vida. Fato semelhante a este ocorreu para alguns indivíduos, que as vezes mostravam atividade no loco 3 e não apresentavam no loco 4 .

\section{Diaforase (DIA)}

Foram quatro os locos presentes nessa enzima para as plantas matrizes; destes, apenas o loco dois (Dia-2) apresentou condição de interpretação, sendo uma enzima monomérica com dois alelos (Figura 4). Nas progênies, a enzima apresentou baixa resolução, inviabilizando a interpretação, necessitando assim ser totalmente descartada. 

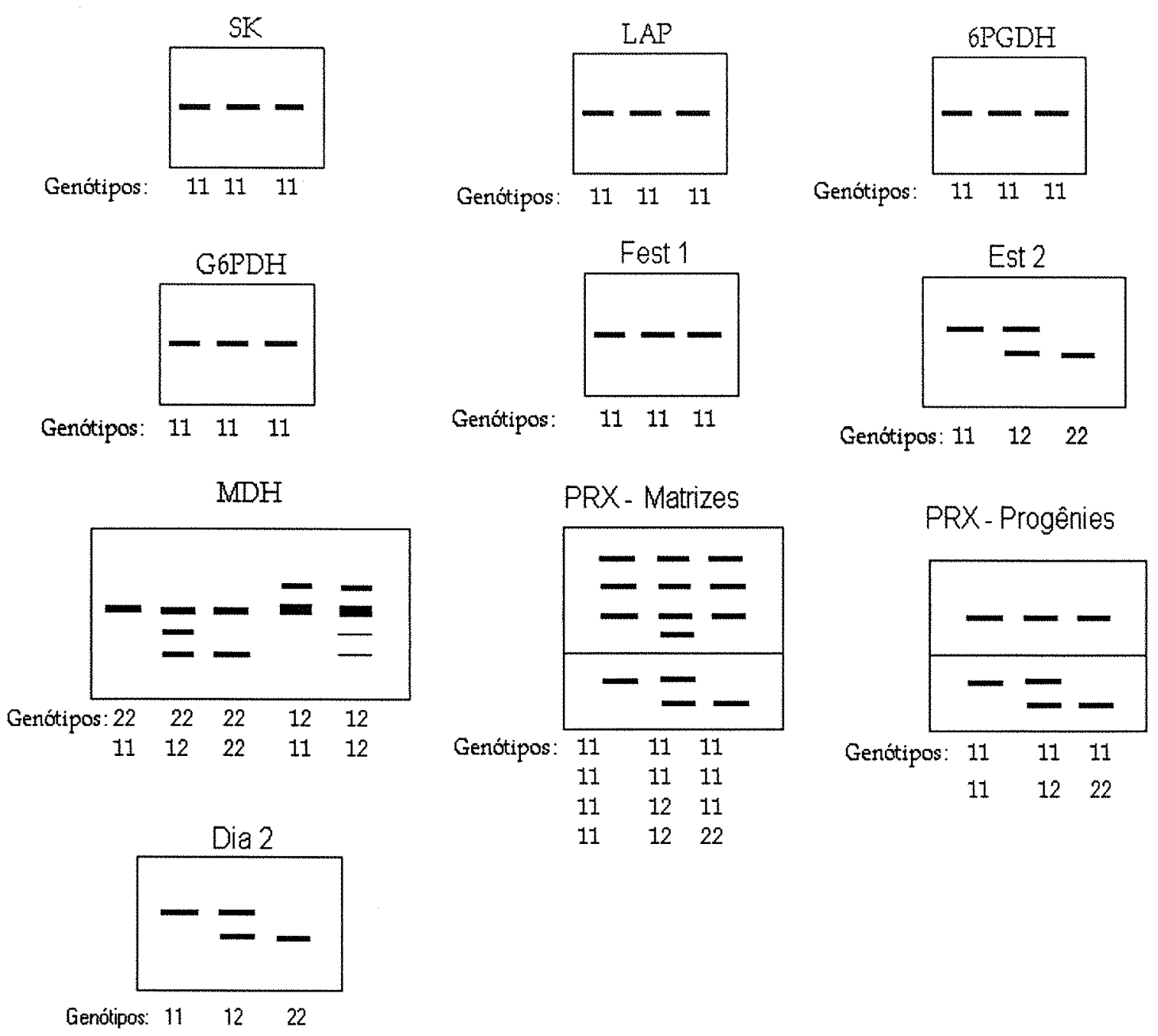

Figura 4 - Zimograma dos sistemas isoenzimáticos das subpopulações de Bertholletia excelsa em floresta, pastagens com 2 anos e 4 anos de formação.

\subsection{Frequências alélicas}

Na Tabela três são apresentadas as freqüências de 19 alelos de 13 locos para matrizes e progênies nas três subpopulações estudadas de Bertholletia excelsa. 
Tabela 3. Freqüências alélicas das três subpopulações de Bertholletia excelsa, por loco para matrizes e progênies. Piracicaba 2001.

\begin{tabular}{|c|c|c|c|c|c|c|c|}
\hline \multirow[t]{2}{*}{ Locos } & \multirow[t]{2}{*}{ Alelo } & \multicolumn{2}{|c|}{ Floresta } & \multicolumn{2}{|c|}{ Pastagem 2 anos } & \multicolumn{2}{|c|}{ Pastagem 4 anos } \\
\hline & & Matrizes & Progênies & Matrizes & Progênies & Matrizes & Progênies \\
\hline Prx-1 & 1 & 1,000 & --- & 1,000 & --- & 1,000 & --- \\
\hline Prx-2 & 1 & 1,000 & --- & 1,000 & -- & 1,000 & $-\cdots$ \\
\hline Prx -3 & $\begin{array}{l}1 \\
2\end{array}$ & $\begin{array}{l}0,982 \\
0.018\end{array}$ & 1,000 & $\begin{array}{l}1,000 \\
0,000\end{array}$ & 1,000 & $\begin{array}{l}1,000 \\
0,000\end{array}$ & 1,000 \\
\hline $\operatorname{Pr} x-4$ & $\begin{array}{l}1 \\
2\end{array}$ & $\begin{array}{l}0,304 \\
0,696\end{array}$ & $\begin{array}{l}0,927 \\
0,073\end{array}$ & $\begin{array}{l}0,383 \\
0,617\end{array}$ & $\begin{array}{l}0,771 \\
0,229\end{array}$ & $\begin{array}{l}0,417 \\
0,583\end{array}$ & $\begin{array}{l}0,659 \\
0,341\end{array}$ \\
\hline Sk & 1 & 1,000 & 1,000 & 1,000 & 1,000 & 1,000 & 1,000 \\
\hline 6pgdh & 1 & 1,000 & 1,000 & 1,000 & 1,000 & 1,000 & 1,000 \\
\hline G6pdh & 1 & 1,000 & 1,000 & 1,000 & 1,000 & 1,000 & 1,000 \\
\hline Lap & 1 & 1,000 & 1,000 & 1,000 & 1,000 & 1,000 & 1,000 \\
\hline Mdh-1 & $\begin{array}{l}1 \\
2\end{array}$ & $\begin{array}{l}0,133 \\
0,867\end{array}$ & $\begin{array}{l}0,172 \\
0,828\end{array}$ & $\begin{array}{l}0,107 \\
0,893\end{array}$ & $\begin{array}{l}0,066 \\
0,934\end{array}$ & $\begin{array}{l}0,130 \\
0,870\end{array}$ & $\begin{array}{l}0,113 \\
0,887\end{array}$ \\
\hline Mdh-2 & $\begin{array}{l}1 \\
2\end{array}$ & $\begin{array}{l}0,483 \\
0,517\end{array}$ & $\begin{array}{l}0,463 \\
0,537\end{array}$ & $\begin{array}{l}0,533 \\
0,467\end{array}$ & $\begin{array}{l}0,485 \\
0,515\end{array}$ & $\begin{array}{l}0,600 \\
0,400\end{array}$ & $\begin{array}{l}0,512 \\
0,488\end{array}$ \\
\hline Fest-1 & 1 & 1,000 & 1,000 & 1,000 & 1,000 & 1,000 & 1,000 \\
\hline Dia-2 & $\begin{array}{l}1 \\
2\end{array}$ & $\begin{array}{l}1,000 \\
0,000\end{array}$ & $\overline{--}$ & $\begin{array}{l}1,000 \\
0,000\end{array}$ & $\cdots$ & $\begin{array}{l}0,907 \\
0,093\end{array}$ & -- \\
\hline Est-2 & $\begin{array}{l}1 \\
2\end{array}$ & $\begin{array}{l}0,741 \\
0,259 \\
\end{array}$ & $\begin{array}{l}0,934 \\
0,066\end{array}$ & $\begin{array}{l}0,500 \\
0,500\end{array}$ & $\begin{array}{l}0,868 \\
0,132 \\
\end{array}$ & $\begin{array}{l}0,500 \\
0,500 \\
\end{array}$ & $\begin{array}{l}0,784 \\
0,216 \\
\end{array}$ \\
\hline $\begin{array}{l}\text { Total da } \\
\text { amostra }\end{array}$ & & 30 & 131 & 30 & 157 & 30 & 145 \\
\hline
\end{tabular}

A subpopulação floresta na geração matrizes apresentou para o loco Prx3 o alelo 2. Para as subpopulações em pastagem esse alelo foi ausente, apresentando a fixação do alelo 1. O fato do alelo 2 Prx-3 ter aparecido apenas na subpopulação floresta demonstra que esse alelo é raro. É possivel que se amostragem fosse aumentada, esse alelo seria amostrado para demais subpopulações, todavia, ainda assim a sua frequência seria baixa. Fato semelhante a Prx-3 foi observado no loco Dia-2, sendo baixa a frequência do alelo 2 nas matrizes da subpopulação P4. O alelo é raro na subpopulação e nas demais subpopulações está com alelo 1 fixado.

No loco Prx-4 pode-se observar que a frequência do alelo 1 para as três subpopulações matrizes foi menor em relação ao alelo 2, entretanto nas progênies essa frequência teve os valores totalmente invertidos, ou seja, a frequência do alelo 1 mostrouse maior que a do alelo 2 (Tabela 3 ). 
As freqüências alélicas apresentadas pelos dois alelos do loco Mdh-1 nas três subpopulações matrizes demonstraram que o alelo 1 é menos freqüente (Tabela 3) em relação ao alelo 2 , e observa-se que este padrão se mantém estável nas frequências alélicas das progênies. As frequências alélicas apresentadas para o loco Mdh2 nas três subpopulações e nas duas categorias avaliadas demonstram que suas proporções são intermediárias. As frequências alélicas estáveis entre subpopulações e categorias, desse sistema enzimático, nos leva a inferir que a deriva ocorrida no loco MDH seja muito pequena.

No loco Est-2 observa-se que as frequências do alelo 1 e 2 para as matrizes das subpopulações P2 e P4 estão em proporções intermediárias $(0,500)$, já na subpopulação floresta a frequência do alelo 1 é um pouco maior em relação ao alelo 2. As frequências alélicas apresentadas para esse loco nas progênies denotam um forte aumento na frequência do alelo mais comum, que é o alelo 1 (Tabela 3).

Observa-se que as frequências alélicas dos locos Prx-4 e Est-2 nas progênies foram mais oscilantes quando comparadas com as matrizes. As variações encontradas no loco Prx-4, no qual um alelo tem frequência muito baixa em uma geração e alta na outra geração, ou então, como no caso de Prx-3 e Dia-2 em que alelos raros presentes em uma subpopulação são ausentes nas demais, sugerem deriva genética (Negrão 1999). A autora cita que oscilações nas frequências alélicas, perdas e fixação de alelos são resultados de deriva genética. Por sua vez, o loco Est-2 indica seleção, pelo fato do alelo mais comum (alelo 1) aumentar a frequência na geração progênies para as três subpopulações. Como as alterações nas frequências alélicas de Prx-4 demonstra que o alelo 2 foi pouco representado nas progênies, pode-se supor que se essas progênies fossem utilizadas para compor uma nova população, o alelo 2 seria representado em baixa frequência. Isso seria uma amostragem genética mal feita, uma vez que essas progênies não estão representando as frequência alélicas das matrizes adequadamente.

As variações encontradas nas frequência alélicas sugerem que esses efeitos podem ser oriundos de amostragem genética e é possível a perda e fixação de alelos nas próximas gerações. 


\subsection{Estrutura Genética}

Os parâmetros utilizados para estimar o coeficiente de coancestralidade de Cockerham foram $\hat{f}, \hat{F}$ e $\hat{\theta}$ p, que correspondem às estimativas de Wrigth, $\hat{F}$ is, $\hat{F}_{\text {IT }}$,

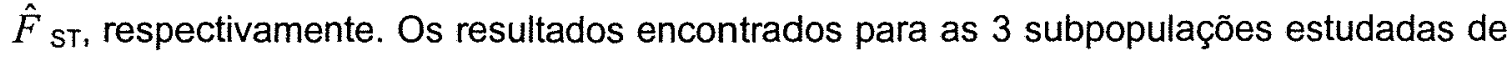
Bertholletia excelsa estão relacionados na Tabela 4.

Tabela 4. Coeficientes de endogamia ( $\hat{f}=$ endocruzamento dentro das subpopulações e $\hat{F}=$ endocruzamento de Wrigth) e coancestralidade $\left(\hat{\theta}_{\mathrm{p}}\right)=$ divergência genética entre subpopulações e $\hat{\theta} f=$ parentesco dentro das famílias) por geração para as três subpopulações de Bertholletia excelsa.

\begin{tabular}{lcccc}
\hline Geração & $\hat{f}$ & $\hat{F}$ & $\hat{\theta}_{\mathrm{p}}$ & $\hat{\theta}_{\mathrm{f}}$ \\
\hline \multirow{2}{*}{ Matrizes } & $-0,133$ & $-0,110$ & 0,020 & $-\ldots$ \\
& $(0,138 \mathrm{a}-0,314)$ & $(0,146 \mathrm{a}-0,238)$ & $(0,065 \mathrm{a}-0,007)$ & \\
Progênies & $-0,069$ & 0,042 & 0,027 & 0,105 \\
& $(-0,314 \mathrm{a}-0,227)$ & $(0,329 \mathrm{a}-0,172)$ & $(0,077 \mathrm{a}-0,007)$ & $(0,251 \mathrm{a} 0,044)$ \\
\hline
\end{tabular}

O coeficiente médio de endocruzamento $(\hat{f})$ dentro das subpopulações (Tabela 4), tanto para matrizes quanto para progênies de B. excelsa, foram negativos, indicando não ocorrer endogamia dentro dos mesmos. Apenas para as progênies o $\hat{F}$ foi positivo $(0,042)$, mas não diferentes de zero.

A divergência genética $(\hat{\theta} p)$ apresentada entre as três subpopulações foi baixa, apenas 0,020 para matrizes e 0,027 para progênies.

O valor estimado para o $\hat{\theta} f$ médio entre locos $(0,105)$ foi inferior ao esperado em progênies de meios irmãos $(0,125)$. Esse fato decorre da frequência alta dos adultos (Tabela 3). Nas progênies, com exceção do loco 1 de Mdh2, todos os outros apresentaram frequência altas. Por exemplo, nos locos Prx-4, Mdh-1 e Est-2 apresentaram sempre um alelo com frequência superior a 0,659. A frequência alta destes alelos, ocorre em todas as progênies de uma subpopulação, logo a variâncias entre progênies diminui. Os intervalos de confiança obtidos para os coeficientes (Tabela 4), tanto para matrizes como para progênies, apresentaram grande amplitude, mas não foram significativos. Apenas o coeficiente de parentesco dentro de familias $(\hat{\theta} f)$ apresentou valor significativo. 
Analisando o coeficiente de endocruzamento de cada subpopulação, para os dados das progênies (Tabela 5), observa-se o alto valor negativo apresentado pela floresta $(-0,302)$, a P4 apresentou valor negativo $(-0,077)$, porem, menor que da floresta, e a P2 apresentou valor baixo, mas positivo $(0,064)$. Fato semelhante ocorreu para o coeficiente de Wrigth $(\hat{F})$, onde os coeficientes foram levemente negativo, com exceção da P2 que apresentou valor maior. Na floresta $\times$ P2 existe um pequeno excesso de endogamia dentro das progênies e no conjunto das populações. A causa, deste fato, pode ser o comportamento dos polinizadores visitando flores da mesma árvore ou de árvores aparentadas, resultando em endogamia por auto-fecundação e cruzamento entre aparentados. É possível que a diferença na endogamia encontrada para as subpopulações estudadas para a geração de progênies, seja reflexo da alteração antrópica exercida para formação das pastagens, bem como do manejo das mesmas.

Tabela 5. Coeficientes de endogamia $(\hat{f}=$ endocruzamento dentro das subpopulações e $\hat{F}=$ endocruzamento de Wrigth) e coancestralidade ( $\hat{\theta} \mathrm{f}=$ parentesco dentro das familias) para progênies das três subpopulações de Bertholletia excelsa, analisadas individualmente.

\begin{tabular}{lccc}
\hline \multicolumn{1}{c}{ Subpopulações } & $\hat{f}$ & $\hat{F}$ & $\hat{\theta} \mathbf{f}$ \\
\hline Floresta & $-0,302$ & $-0,123$ & 0,136 \\
Pastagem 2 anos & 0,064 & 0,112 & 0,051 \\
Pastagem 4 anos & $-0,077$ & $-0,001$ & 0,070 \\
\hline
\end{tabular}

O coeficiente de parentesco dentro de progênies $(\hat{\theta} f)$ oscilou para cada subpopulação (Tabela 5), mas a floresta foi a que apresentou o maior coeficiente, estando inclusive um pouco acima do estabelecido para famílias de meios irmãos $(0,125)$. Para as duas subpopulações em pastagens o valor ficou bem abaixo.

O coeficiente de endocruzamento $(\hat{f})$ encontrado para as três subpopulações estudadas, tomadas duas a duas (Tabela 6), apresentaram valores negativos. Para as matrizes, o coeficiente de Wrigth $(\hat{F})$ foi negativo (Tabela 5 ). Porém, para as progênies todos os pares foram positivos (Tabela 6 ), inclusive as combinações que apresentaram os maiores coeficientes de endocruzamento foram P2 x P4 $(0,058)$ e Floresta x P2 $(0,046)$, sendo o dobro do obtido para floresta x P4 $(0,021)$. 
O coeficiente de parentesco dentro de familias $(\hat{\theta} f)$ para as progênies foi menor entre a P2 x P4 $(0,068)$ e o maior foi entre Floresta $\times$ P4 $(0,149)$ ), indicando a presença de progênies com grau de parentesco superior ao de meios irmãos (Tabela 6).

Tabela 6. Coeficientes de endogamia ( $\hat{f}=$ endocruzamento dentro das subpopulações e $\hat{F}=$ endocruzamento de Wrigth) e coancestralidade $(\hat{\theta} \mathrm{p}=$ divergência genética entre subpopulações e $\hat{\theta} f=$ parentesco dentro das famílias) para matrizes (Matr.) e progênies (Prog.) das três subpopulações de Bertholletia excelsa, tomadas duas a duas.

\begin{tabular}{lccccccc}
\hline Subpopulações & \multicolumn{2}{c}{$\hat{f}$} & \multicolumn{2}{c}{$\hat{F}$} & \multicolumn{2}{c}{$\hat{\theta}$} & $\hat{\theta} f$ \\
\cline { 2 - 7 } & Matr. & Prog. & Matr. & Prog. & Matr. & Prog. & Prog \\
\hline Floresta x P2 anos & $-0,138$ & $-0,066$ & $-0,149$ & 0,046 & $-0,009$ & 0,021 & 0,106 \\
Floresta x P4 anos & $-0,204$ & $-0,149$ & $-0,158$ & 0,021 & 0,038 & 0,059 & 0,149 \\
P2 anos x P4 anos & $-0,035$ & $-0,010$ & $-0,011$ & 0,058 & 0,023 & 0,008 & 0,068 \\
\hline
\end{tabular}

Para as matrizes das subpopulações floresta x P2 a divergência genética $(\hat{\theta} \mathrm{p})$ foi negativa, sugerindo que estas populações são idênticas, logo trata-se de uma mesma população. Todavia, para floresta $\times$ P4 e P2 x P4 uma pequena divergência é apresentada, $3,8 \%$ e 2,3\%, respectivamente. Neste caso, a divergência pode ter sido causada por deriva genética em $\mathrm{P} 4$ resultando em estruturação dentro das populações. Nas progênies, todos os pares combinados de subpopulações apresentaram divergência, sendo a mais alta entre floresta $\times \mathrm{P} 4$, com $5,9 \%$, em concordância ao observado para as matrizes. Tudo indica que a divergência foi maior entre floresta $\times \mathrm{P} 4$, possivelmente, em função do menor número de remanescentes habilitados a reprodução em função da idade de formação da pastagem e de polinizadores capacitados a forragear em floresta e em pastagens.

Buckley et al. (1988) usando o coeficiente de Nei encontraram uma divergência gênica entre populações naturais de $B$. excelsa de apenas $3,75 \%$, verificando uma maior diversidade dentro das populações. Esses autores acreditam que as populações de $B$. excelsa necessitam ser grandes, pois o fluxo gênico é muito extenso e possui vários elos de cruzamento sobre uma grande área, possibilitando assim o surgimento de uma maior variação genética.

As taxas negativas dos f e $F$ indicam ausência de endogamia, já a média positivas de $F(0,042)$ encontradas para as subpopulações estudadas de $B$. excelsa são 
decorrentes da pequena divergência observada em alguns locos, e está dentro dos valores encontrados para a maioria das espécies tropicais (Tabela 7).

Tabela 7. Divergência genética entre populações de espécies arbóreas tropicais. $\left(\hat{F}_{\mathrm{ST}}\right.$ Wrigth, 1951 e $\hat{\theta} \mathrm{p}$ - Cockermam, 1969).

\begin{tabular}{|c|c|c|c|}
\hline Espécies & $\hat{F}_{\mathrm{ST}}$ & $\hat{\theta} \mathrm{p}$ & Fonte \\
\hline Aspidosperma polineuron & 0,061 & & Maltez (1997) \\
\hline Astrocaryum mexicanum & 0,039 & & Eguiarte et al. (1992) \\
\hline Bertholletia excelsa & & 0,042 & Este trabalho \\
\hline Cecropia obtusifolia & 0,029 & & Alvarez-Buylla \& Garray (1994) \\
\hline Cedrela fissilis & 0,089 & & Gandara (1997) \\
\hline Chorisia speciosa & 0,183 & & Souza (1997) \\
\hline Cryptocaria moschata & 0,107 & 0,123 & Moraes (1997) \\
\hline Esenbeckia leiocarpa & 0,005 & & Seoane (1998) \\
\hline Euterpe edulis & 0,031 & 0,023 & Reis (1996) \\
\hline Genipa americana & & 0,006 & Sebben (1997) \\
\hline Hevea brasiliensis & 0,007 & & Paiva (1992) \\
\hline Myracrodum urundeuva & 0,035 & & Moraes (1992) \\
\hline Ocotea tenera & 0,128 & & Gibson e Wrigth (1995) \\
\hline Psycotris faxlucens & 0,026 & & Perez-Nasser et al. (1993) \\
\hline Pterocarpus macrocarpus & 0,121 & & Liengsiri et al. (1995) \\
\hline Syagrus romanzoffiana & & 0,259 & Negrão (1999) \\
\hline
\end{tabular}

Fonte: Modificado de Negrão (1999)

Os valores encontrados para $\hat{\theta} f$ indica que pode estar ocorrendo um maior parentesco $(0,149)$ dentro das familias de $B$. ecelsa. Assim, para o bom êxito na fundação de novas populações será necessário estar utilizando um menor numero de sementes por árvores e um maior numero de árvores, ou seja aumentar a amostragem genética para diminuir os efeitos da fragmentação.

\subsection{Sistema de Reprodução}

\subsubsection{Taxa de Cruzamento}

Das 90 árvores matrizes selecionadas para o estudo da estrutura genética de $B$. excelsa observou-se que apenas $43 \%$ - $60 \%$ produziram frutos, e que as matrizes em floresta produziram cerca de 3 a 4 vezes mais ouriços por árvores quando comparadas com as subpopulações em pastagens. Todavia esta observação na área de estudo foi 
estatística, merecendo assim uma mensuração mais precisa quanto à produção de frutos por árvore em remanescentes em pastagens.

A taxa de cruzamento multilocos $\left(\hat{t}_{\mathrm{m}}\right)$ obtida para as três subpopulações de $B$. excelsa foi alta: 1,0 para $\mathrm{P} 2,0,931$ para $\mathrm{P} 4$ e 0,927 para floresta com média de 0,952 (Tabela 8 ). Pode-se dizer que praticamente não houve diferença na taxa de cruzamento intersubpopulações.

A taxa de cruzamento entre parentes $\left(\hat{t}_{\mathrm{m}}-\hat{t}_{\mathrm{s}}\right)$ estimada para as três subpopulações (Tabela 8), com valores de $0,007,0,029$ e 0,044 para P2, P4 e floresta, respectivamente, e com média de 0,026 para população. A taxa de autofecundação (1 $\hat{t}_{\mathrm{m}}$ ) apresentou valor nulo, 0,069 e 0,073 para P2, P4 e floresta, respectivamente e média de 0,047 para a população.

Tabela 8. Estimativa da taxa de cruzamento multilocos $\left(\hat{t}_{\mathrm{m}}\right)$, loco simples $\left(\hat{t}_{\mathrm{s}}\right)$ para as três subpopulações de Bertholletia excelsa.

\begin{tabular}{|c|c|c|c|c|c|c|c|}
\hline \multirow[t]{3}{*}{ Locos } & \multirow[t]{3}{*}{ Alelos } & \multirow{2}{*}{\multicolumn{2}{|c|}{$\begin{array}{l}\text { Pastagem } 2 \text { anos } \\
\text { Frequencia Alélica* }\end{array}$}} & \multirow{2}{*}{\multicolumn{2}{|c|}{$\begin{array}{l}\text { Pastagem } 4 \text { anos } \\
\text { Frequencia Alélica* }^{*}\end{array}$}} & \multicolumn{2}{|c|}{ Floresta } \\
\hline & & & & & & Freque & Jélica* \\
\hline & & Pólen & Óvulo & Pólen & Óvulo & Pólen & Óvulo \\
\hline \multirow{2}{*}{$\operatorname{Prx}-4$} & 1 & 0,765 & 0,682 & 0,698 & 0,500 & 0,856 & 0,950 \\
\hline & 2 & 0,235 & 0,318 & 0,302 & 0,500 & 0,144 & 0,050 \\
\hline \multirow[t]{2}{*}{ Mdh-1 } & 1 & 0,008 & 0,136 & 0,120 & 0,100 & 0,146 & 0,200 \\
\hline & 2 & 0,992 & 0,864 & 0,880 & 0,900 & 0,854 & 0,800 \\
\hline \multirow[t]{2}{*}{ Mdh-2 } & 1 & 0,362 & 0,636 & 0,650 & 0,400 & 0,783 & 0,300 \\
\hline & 2 & 0,638 & 0,364 & 0,350 & 0,600 & 0,217 & 0,700 \\
\hline \multirow[t]{2}{*}{ Est-2 } & 1 & 0,815 & 0,909 & 0,526 & 0,952 & 0,860 & 0,952 \\
\hline & 2 & 0,185 & 0,091 & 0,474 & 0,048 & 0,140 & 0,034 \\
\hline$\hat{t}_{\mathrm{m}}$ & & \multicolumn{2}{|c|}{$1,000(0,001)$} & \multicolumn{2}{|c|}{$0,931(0,076)$} & \multicolumn{2}{|c|}{$0,927(0.061)$} \\
\hline$\hat{t}_{\mathrm{s}}$ & & \multicolumn{2}{|c|}{$0,974(0,007)$} & \multicolumn{2}{|c|}{$0,901(0,055)$} & \multicolumn{2}{|c|}{$0.871(0.047)$} \\
\hline$\hat{t}_{\mathrm{m}}-\hat{t}_{\mathrm{s}}$ & & \multicolumn{2}{|c|}{$0,026(0,007)$} & \multicolumn{2}{|c|}{$0,030(0,029)$} & \multicolumn{2}{|c|}{$0.055(0.044)$} \\
\hline $1-\hat{t}_{\mathrm{m}}$ & & \multicolumn{2}{|c|}{0,000} & \multicolumn{2}{|c|}{0,069} & \multicolumn{2}{|c|}{0,073} \\
\hline
\end{tabular}

A estimativa da taxa de cruzamento obtida para as três subpopulações de Bertholletia excelsa, dentro do parâmetro $\hat{t}$ de Clegg (1980), indica que a espécie em seu evento reprodutivo foi predominantemente de fecundação cruzada (alógamo). Os 
parâmetros são usados para nos dar base sobre que tipo de taxa de cruzamento uma determinada espécie pratica, não indicando necessariamente, que uma espécie que realiza a fecundação cruzada não permita pequenas porcentagens de cruzamentos entre aparentados ou autofecundação. Na verdade, as pequenas taxas de parentesco $(0,026)$ e de autofecundação $(0,047)$ encontrada para a população de $B$. excelsa podem constituir mecanismos que a espécie desenvolveu para assegurar sua reprodução e perpetuação. A maior parte das espécies de árvore tropicais possui sistema de cruzamento por fecundação cruzada e, ao obter as estimativas dos parâmetros de cruzamentos, na maior parte dos resultados são detectadas pequenas porcentagens de parentesco e autofecundação.

A taxa de cruzamento obtida neste estudo são muito parecidas com a encontrada em outros estudos de espécies tropicais (Tabela 2). Couratari multiflora pertencente à mesma familia de Bertholletia, apresenta um indivíduos a cada 10 hectare e dispersa as sementes pelo vento (anemocoria). A estimava da taxa de cruzamento de Couratari multiflora foi de 0,953 (Lepsch-Cunha, 1996), bem similar a encontrada para população de $B$. excelsa $(0,952)$, nesse estudo. $\mathrm{Na}$ Tabela 9 apresenta-se exemplos de espécies tropicais com estimativa de cruzamento semelhantes a obtida neste estudo.

Tabela 9. Taxa de Cruzamento $\left(\hat{t}_{\mathrm{m}}\right)$ em populações naturais de espécies tropicais. Piracicaba 2001.

\begin{tabular}{lcl}
\hline \multicolumn{1}{c}{ Espécie } & $\hat{t}_{\mathrm{m}}$ & \multicolumn{1}{c}{ Referência } \\
\hline Cedrela fissilis & 0,92 & Gandara, 1995 \\
Spondia mombin & 1,14 & Stacy et al. 1996 \\
Chorisia speciosa & 0,88 & Souza, 1997 \\
Genipa americana * $^{*}$ & 0,82 & Sebben, 1998 \\
Esenbeckia leiocarpa $_{\text {Myracrodruom urundeuva* }}^{*}$ & 0,99 & Seoane, 1998 \\
Jacaranda copaia & 0,93 & Lacerda et al., 1999 \\
Cedrela odorata & 0,94 & James et al. em elaboração \\
Bertholletia excelsa & 0,97 & James et al., em elaboração \\
\hline
\end{tabular}

*Espécie dióica

O'Malley et al. (1988) estudando populações naturais de Bertholletia excelsa estimou uma taxa de cruzamento em $t_{m}$ 0.85. As estimativas da $t_{m}$ obtidas para as três subpopulações nesse estudo, foram superiores às encontradas pelos autores. Um 
fator que pode explicar a menor taxa de cruzamento encontrada por esses autores, pode ser o número de locos polimórficos utilizados na análise estatística, uma vez que os mesmos utilizaram apenas dois locos polimórficos e o trabalho atual, quatro.

Bertholletia excelsa é considerada como sendo uma espécie de baixa densidade (1/ha), ocupa o dossel, com polinização especializada por abelhas de grande porte em função de sua barreira física adaptada ao longo da evolução e, dispersão dos seus frutos por mamíferos roedores capacitados a abrir a espessa cápsula e deposição das sementes em sitios apropriados para germinação (Muller et al., 1980; Nelson et al., 1985, Lepsch-Cunha, 1996; Maués 1999 e Baider, 2000).

Analisando o histórico de vida de $B$. excelsa, esperava-se, a princípio, que a taxa de cruzamento nas subpopulações em pastagens divergissem da floresta por estarem isolados de seu ambiente natural (floresta). Essa suposição baseava-se, a principio, na dificuldade que os agentes polinizadores teriam em sair do ambiente natural para realizarem a polinização em área totalmente aberta, como no caso das subpopulações em pastagens. Assim, o evento reprodutivo, por contar com baixo número de polinizadores ou nenhum, tenderia a ter uma taxa de cruzamento inferior à apresentada para área de floresta, por favorecer um maior número de cruzamentos entre aparentados e/ou autofecundação. Entretanto, como já vimos, essa não foi a tendência observada em nossos dados. Pelo contrário, as estimativas da taxa de cruzamento foram altas tanto na floresta como para as duas idades de pastagens.

Estudando a biologia reprodutiva e genética de Dinizia excelsa, em ambientes similares ao realizados para $B$. excelsa, Dick (2001) verificou que em árvores remanescentes em pastagens as abelhas africanas (Apis melifera scutellata) estão substituindo as abelhas nativas (Meliponini) e fazendo o papel de polinizadoras. $\mathrm{Na}$ produção de frutos apresentada para Dinizia excelsa, Dick observou aumento de três a quatro vezes no número de frutos produzidos por essas árvores remanescentes em pastagens quando comparados com a floresta. Todavia, a estimativa da taxa de cruzamento evidenciou $10 \%$ a mais de auto-fertilização nos remanescentes em pastagens quando comparados com os da área fragmentada e floresta contínua.

Ao que tudo indica, Dinizia excelsa parece ter um sistema de reprodução mais flexivel que $B$. excelsa, que permite sob pressão, alterar sua taxa de cruzamento visando garantir sua reprodução. Já, $B$. excelsa, mesmo sob pressão, não apresentou alterações na taxa de cruzamento nas subpopulações em pastagens. Isso pode ser 
entendido, pois a espécie despende um gasto muito grande para produção dos frutos e sementes com envoltórios lenhosos e têm uma área restrita $(5 \mathrm{Km})$ de dispersão de suas sementes. Assim, para espécie, pode ser mais vantajoso assegurar uma menor quantidade de frutos, mas com uma porcentagem menor de endogamia em suas progênies.

Dick (2001) verificou mudança de polinizador em árvores remanescentes de Dinizia excelsa em pastagem, com consequente aumento na taxa de auto-fecundação, mas nesse trabalho não foi abordado esse aspecto. Todavia, Centeno ${ }^{1}$ (em preparo) estudando a polinização de Castanheira em floresta e em pastagem em Madre de Dios no Peru observou nove espécies de abelhas que visitam flores de $B$. excelsa na floresta. Destas, apenas quatro espécies de abelhas forrageiam flores de $B$. excelsa em remanescentes em pastagem. Dos gêneros identificados até o momento, Xylocopa sp foi a espécie comum e com maior porcentagem de visitação nas duas áreas estudadas. Já Eulaema $s p$, Exaerete $s p$ e três espécie ainda não identificada foram restritas à floresta.

Esses resultados demonstram que algumas espécies de abelhas que polinizam Castanha do Brasil, tem seus hábitos de forragearem restritos à floresta, confirmando a predição de Nelson et al. (1985) de que algumas dessas espécies forrageiam dentro da floresta e áreas secundárias, mas de maneira pouco provável em áreas totalmente abertas. Desta forma, é possivel que a composição de insetos polinizadores de $B$. excelsa em pastagens no Brasil também possa ser diferente em relação a floresta, assim como o é em áreas de plantios em diferentes regiões geográfica para a espécie (Tabela 1).

Apesar de ter sido detectado aumento na taxa de auto-fertilização de Dinizia excelsa nas árvores remanescentes em pastagem, Dick (2001) observou aumento na produção de frutos nesse remanescentes. Já, nas duas subpopulações de $B$. excelsa em pastagens a taxa de cruzamento foi praticamente a mesma encontrada na floresta, mas o número de frutos produzidos por árvore remanescente foi menor. Assim, os dados obtidos nesse trabalho aliado aos de Centeno et.al (Em elaboração) e Moritz (1984), que não obteve frutificação nos sistemas de auto-cruzamento realizados para espécie, pode-se inferir que $B$. excelsa possui algum sistema de auto-incompatibilidade (SI).

O SI explicaria, também, a quase inexistência de parentesco e autogamia apresentadas nas progênies das subpopulações de $B$. excelsa em pastagens. Partindo

${ }^{1}$ CENTENO, P. et. al. Estudio de polinizacion em bosques naturales de Madre de Dios: observacion sobre floracion de castaña (Bertholletia excelsa H.B.K.). (Em elaboração). 
desse pressuposto, pode-se inferir que todas as progênies que chegaram à maturação e foram coletadas em pastagens para esse estudo, realmente não poderiam apresentar aumento na taxa de auto-fecundação. Isso porque, os frutos que possivelmente tiveram alta porcentagem de parentesco, devem ter sido abortados pelo mecanismo de autoincompatibilidade da espécie, não sendo assim possível estimar a alteração da taxa de cruzamento.

Esse fato também pode ser o que levou Buckley et al. (1988) a afirmarem que a taxa de cruzamento de $B$. exce/sa que encontraram em populações naturais sugere que seu sistema reprodutivo produza sementes predominantemente de fecundação cruzada, pois a circulação de genes dentro da população de plantas está condicionada pelo grau de compatibilidade genética entre os indivíduos da população. A presença de auto-incompatibilidade gametofítica pode impedir certos tipos de cruzamento, como no caso de espécies com dispersão de sementes restritas, onde possivelmente plantas da espécie na vizinhança devam ter alelos de auto-incompatibilidade comuns, o que pode impedir ou dificultar o cruzamento. Assim, a probabilidade de plantas de uma mesma vizinhança serem fertilizadas por planta mais distantes é maior (Levin, 1981 e Martins, 1987).

Várias famílias de Angiospermas hermafroditas apresentam sistema de auto-incompatibilidade (SI) (Ramalho et al., 1984), mas são poucos os estudos desenvolvidos nesse enfoque para espécies tropicais. Dentre essas, pode-se citar Theobroma cacao e Melaleuca capitata. O sistema de cruzamento de Theobroma cacao possui variação quanto a sua taxa de auto-incompatibilidade, apresenta grande incompatibilidade no seu centro de distribuição (pé da vertente a leste dos Andes), e a medida que se distancia do seu centro ocorre uma diminuição da proporção de indivíduos auto-incompativeis, bem como da variabilidade genética da população (Roche, 1978 citado por Kageyama, 1986). Segundo Kageyama (1986), algumas espécies endêmicas de uma região, ao serem introduzida em outra região para cultivo, podem alterar seu sistema de cruzamento, aumentando sua taxa de autofecundação ou tornando-se totalmente autógama, como é o caso de Hevea brasiliensis e Leucaena leucocephala.

O fruto de $B$. excelsa, durante o processo evolutivo, da mesma forma que sua flor, adequou-se ao dispersor e às condições sucessionais. No caso do processo de germinação da semente e até certo estadio de plântula, as condições de sombreamento e umidade precisam ser adequadas para germinação e 
estabelecimento das mesmas. Observou-se que as progênies das subpopulações em pastagens possuem a mesma capacidade de germinação e crescimento em viveiro que as da floresta (obs. pessoal), ou seja, são indivíduos habilitados a estabelecerem novas populações.

Em pastagem, que é o extremo oposto ao ambiente natural da Castanha do Brasil, há constante pisoteio pelo gado e, na grande maioria das vezes, 0 fogo é utilizado com agente renovador do pasto. Assim, os frutos originados nesse ambiente pelas árvores remanescentes, por não terem as condições básicas para germinação e desenvolvimento, não podem se estabelecer. Fatores como alta luminosidade e temperatura, baixa umidade e a falta do dispersor dos frutos da espécie, conciliados ao uso da pastagem, são ao que tudo indica, os responsáveis pela ausência de germinação e estabelecimento das sementes originadas em pastagem. Desta forma, os frutos produzidos em pastagens, apesar de viáveis, não contribui para o incremento genético nessas subpopulações e populações do entorno da espécie.

Assim, pode-se levantar a hipótese de que as sementes produzidas em menor quantidade nas árvores das pastagens não apresentam grandes diferenças genética como reprodutivas. Mas, isso não significa que não esteja ocorrendo problemas reprodutivos e genéticos nas subpopulações de pastagens, que poderiam estar ocorrendo nas sementes dos frutos abortados.

\subsubsection{Fluxo Gênico}

As estimativas do fluxo gênico aparente para as três subpopulações de Bertholletia excelsa são mostradas na Tabela 10.

Tabela 10. Fluxo gênico $(\mathrm{Nm})$ obtido a partir de estimativas de divergência genética $\left(\hat{\theta}_{\mathrm{p}}\right)$ para as progênies de três subpopulações Bertholletia excelsa tomadas duas a duas, em Xapuri - Acre.

\begin{tabular}{lcc}
\hline Subpopulações & $\hat{\theta}_{\mathrm{p}}$ & $\hat{N} \mathrm{~m}$ \\
\hline Floresta x P2 & 0,021 & 2,80 \\
Floresta x P4 & 0,059 & 0,98 \\
P2 x P4 & 0,008 & 9,28 \\
\hline
\end{tabular}


Os maiores números de migrantes $(\mathrm{Nm})$ obtidos entre cada par de subpopulações foram entre a floresta x P2 $(2,80)$ e P2 x P4 $(9,28)$, e o menor foi entre floresta x P4 $(0,98)$.

O valor de fluxo gênico calculado nesse estudo foi baseado a partir da divergência genética. Assim, é evidente que os pares de subpopulações que apresentaram menores índices de fluxo gênico foram os que tiveram maiores divergências entre si, e o par de combinação com maior índice de fluxo gênico, apresentou menor divergência.

A diferenciação genética em populações é inversamente relacionada ao número de migrantes $(\mathrm{Nm})$. Quando o $\mathrm{Nm}$ é $\geq 1,0$ indica que um ou mais indivíduos migram por geração, assim os efeitos da migração são suficientes para contrapor os efeitos da deriva, impedindo a divergência entre populações (Wrigth, 1931).

A estimativa de $\hat{\theta}_{\mathrm{p}}$ obtidas entre cada par de subpopulações de $B$. excelsa, em termos gerais, é muito pequena, quando comparada com resultados de outras espécies tropicais. Analisando a divergência entre as subpopulações estudadas, pode-se inferir, uma tendência crescente na divergência em relação as idades das pastagens com a floresta. $O$ valor obtido entre floresta $\times$ P4 foi o dobro do observado para floresta $x$ P2. Assim, pode-se sugerir, que as subpopulações floresta $\times$ P4 estão mais distantes geneticamente quando comparada com floresta $x$ P2. Já, a estimativa de divergência entre as duas idades de pastagens foi mais baixa que as outras duas combinações.

Não é esperado que P4, por estar geograficamente mais próxima da floresta, apresente uma divergência maior. Contudo, é necessário lembrar que essa pastagem possui quatro anos de formação e sofreu queimada por dois anos consecutivos. A P2 é uma área, geograficamente mais distante da floresta, com dois anos de formação e também sofreu queimada por dois anos consecutivos, mas as árvores remanescentes nesta área apresentam estado físico melhor que os da P4. Assim, pode-se supor que no passado havia trocas gênicas entre floresta $\times \mathrm{P} 4$ por se tratar de mata contínua, mas atualmente esse fluxo pode estar sendo restringido, provavelmente, em decorrência da barreira física exercida pela fragmentação. Desta forma, a redução no número de árvores remanescentes com vitalidade para reprodução e de espécies de abelhas com capacidade para forragear em floresta e em pastagem, como constatado por Centeno (em preparo), deve ser os principais responsáveis no aumento de divergência entre esses dois ambientes distintos, refletindo assim, na diminuição do fluxo gênico. É possível que entre a floresta e a P2 essa tendência ainda não seja tão evidente, por se tratar de uma fragmentação mais 
recente e as progênies avaliadas serem frutos resultantes de apenas um anos após a fragmentação (considerar que o fruto leva cerca de 12 meses para maturação), podendo não estar expressando ainda os reflexos da baixa movimentação de fluxo gênico entre essas duas áreas.

O alto fluxo observado entre as duas subpopulações em pastagens, por sua vez, pode ser um reflexo do acúmulo de trocas gênicas ocorridos em eventos reprodutivos passados, quando essas áreas ainda eram um contínuo florestal e, adicionado a isso, atualmente, espécies de abelhas capacitadas a forragearem Castanha do Brasil em condições de pastagem podem estar realizando sua polinização, favorecendo assim, um maior fluxo gênico entre si do que quando comparado com a floresta. Vale ressaltar que esse fluxo, apesar de alto, pode não estar representando os remanescentes em pastagem no todo, e sim da pequena quantidade de frutos por árvores que conseguiram chegar a maturação.

A divergência total encontrada no presente estudo foi menor $(0,029)$ do que a estimada por Buckley et al. (1988) entre populações naturais desta espécie $(0,037)$. O autor citado atribui a baixa divergência entre populações ao eficiente mecanismo de dispersão de pólen sobre uma extensa área de floresta.

Govindaraju (1988a) estimou a diferenciação genética entre populações $\left(G_{s t}\right)$ de 115 espécie de diversos gêneros, historias de vida e condições ecológicas e encontrou que as espécies com mecanismos de autopolinização são as que apresentam maiores divergências entre populações, as polinizadas por vento apresentam as menores divergências e as polinizadas por animais apresentam divergências intermediárias.

Dentro da categoria das espécies polinizadas por animais, pode-se dizer que as divergências encontradas para as subpopulações de $B$. excelsa são tão baixas, que podem até igualar-se a valores de divergência encontrados, por Govindaraju (1988a), entre algumas populações de espécies polinizadas pelo vento.

A análise de fluxo gênico realizada por Govindaraju (1988a) demonstrou que as espécies polinizadas por animais obtiveram uma taxa de migrantes de 1,2. Hamrick (199?) encontrou dados entre 0,244 - 13,90. Na Tabela 11 é apresentado número de migrantes em populações naturais de espécies tropicais. 
Tabela 11. Número de migrantes $(\mathrm{Nm})$ em populações naturais de espécies tropicais, com base na abordagem de Weir e Cockerham (1984). Piracicaba 2001.

\begin{tabular}{llll}
\hline Espécie & $\mathrm{Np}$ & $\mathrm{Nm}$ & \multicolumn{1}{c}{ Referencia } \\
\hline Euterpe edulis & & & Reis, 1996 \\
adultos & 8 & 15,38 & \\
progênies & 7 & 11,67 & \\
Syagrus romanzoffiana & 3 & 16,11 & Negrão, 1999 \\
Hevea brasiliensis & 2 & 8,08 & Paiva et al., 1994b \\
Myracrodruom urundeuva & 2 & 4,85 & Moraes, 1992 \\
Cariniana legalis & 2 & 4,46 & Herrit, 1991 \\
Esenbeckia leiocarpa & 2 & 1,29 & Seoane et al., 2000 \\
Bertholletia excelsa & 3 & 4,35 & Este trabalho \\
\hline
\end{tabular}

Fonte: adaptado de Reis (1996).

$\mathrm{Np}=$ número de populaçōes estudadas

A análise do fluxo gênico obtido neste estudo estão dentro dos valores encontrados por Govindaraju (1988a), Hamrick (1987) e Tabela 11, bem como do número de migrantes proposto por Wrigth (1931). Pode-se dizer então que, no passado, o fluxo gênico era amplo o suficiente para contrapor efeitos de deriva genética, a que favoreceu a similaridade entre subpopulações e amenizou os efeitos de deriva genética não permitindo que as subpopulações divergissem. Atualmente, as condições ambientais das três subpopulações não são homogêneas e, futuramente, a divergência genética entre as mesmas pode aumentar, reduzindo assim o número de migrantes entre essas subpopulações ou até mesmo entre populações da espécie mais próxima nessa área geográfica.

Vale ressaltar que remanescentes de Castanha do Brasil com vitalidade para se reproduzir são elos importantes podendo contribuir para o incremento genético. Apesar dos frutos nesse novo ambiente serem subtilizados do ponto de vista de dinâmica populacional, o pólen produzido por essas árvores remanescentes contribuem para manutenção da variabilidade genética intersubpopulações. 


\section{5 Índices de Diversidade}

A heterozigosidade encontrada analisando-se as matrizes dentro de cada subpopulação variou entre 0,123 (floresta) a $0,146(\mathrm{P} 4)$ e nas análises das progênies de 0,105 (floresta) a 0,149 (P4) (Tabela 12). A heterozigosidade média das 3 subpopulações estudadas foi de 0,133 para as matrizes e 0,123 nas progênies, o número médio de locos polimórficos foi de $35,90 \%$ e $40,0 \%$, respectivamente.

O coeficiente de endogamia $\left(\hat{F}_{\text {is }}\right)$ foi levemente positivo apenas para as progênies da P2 $(0,086)$. Entretanto nas demais subpopulações, tanto matrizes como progênies, apresentaram coeficiente negativo ou zero indicando não haver parentesco (Tabela 12).

O número médio de alelos foi de 1,36 para matrizes e 1,40 para as progênies, e o número médio de alelos por loco polimórfico foi de 2,0 para matrizes e progênies.

Tabela 12. Heterozigosidade média esperada $\left(\hat{H}_{\mathrm{e}}\right)$ e observada $(H o)$, coeficiente de endogamia de Wrigth $\left(\hat{F}_{\text {is }}\right)$, porcentagem de locos polimórficos (P\%) a $99 \%$, número médio de alelos por loco $(\hat{A})$, número médio de alelos por locos polimórficos (AP), e tamanho médio da amostra $(\bar{N})$ em subpopulações (Spop's) de Castanha do Brasil. Piracicaba 2001.

\begin{tabular}{ccccccccc}
\hline & Spop's & $\hat{H}_{\mathrm{e}}$ & $H o$ & $\hat{F}_{\text {is }}$ & $\mathrm{P}(\%)$ & $\hat{A}$ & AP & $\bar{N}$ \\
\hline Matrizes & Floresta & $0,123(0,054)$ & $0,132(0,060)$ & $-0,057$ & 38,46 & 1,38 & & 29,31 \\
& P2 anos & $0,130(0,060)$ & $0,158(0,081)$ & $-0,208$ & 30,77 & 1,31 & 27,31 \\
& P4 anos & $0,146(0,059)$ & $0,189(0,089)$ & $-0,157$ & 38,46 & 1,38 & 28,54 \\
\hline \multirow{5}{*}{ Progênies } & média & 0,133 & 0,160 & $-0,141$ & 35,90 & 1,36 & 2,0 & 28,38 \\
& Floresta & $0,105(0,053)$ & $0,119(0,074)$ & $-0,034$ & 40,00 & 1,40 & 11,87 \\
& P2 anos & $0,121(0,058)$ & $0,108(0,053)$ & 0,086 & 40,00 & 1,40 & 13,10 \\
& P4 anos & $0,149(0,066)$ & $0,151(0,069)$ & 0,000 & 40,00 & 1,40 & 13,34 \\
\hline & média & 0,123 & 0,126 & 0,020 & 40,00 & & 2,0 & 12,58 \\
\hline
\end{tabular}

De modo geral, pode-se dizer que a heterozigosidade variou muito pouco intersubpopulações. As duas subpopulações em pastagens, tanto matrizes como progênies, apresentaram uma tendência de heterozigosidade um pouco maior que a da floresta. 
A heterozigosidade e o número de locos polimórficos obtidos para as três subpopulações de $B$. excelsa nesse trabalho (Tabela 12) foram um pouco abaixo dos valores encontrado por Buckley et al. (1988) para populações naturais desta espécie. Os referidos autores obtiveram uma taxa de heterozigose de 0.19 e $54.3 \%$ dos locos amostrados sendo polimórficos. Uma explicação plausivel para essa diferença pode estar na distância entre populações, tamanho de amostragem e quantidades de locos polimórficos obtidos por esses autores citados, que contribuiu para que tivessem valores um pouco maior de heterozigosidade e polimorfismo. Esses autores conseguiram $54,3 \%$ dos locos polimórficos, mas relataram que a quantidade de locos polimórficos obtida, foi baixa. Esse fato também foi encontrado em nossa análise, pois dos nove locos analisados apenas cinco foram polimórfico, lembrando que destes, a Esterase fluorescente (FEST) não pôde ser interpretada. Isso indica que a espécie possui baixa variabilidade e polimorfismo, ao menos em isoenzimas.

Alguns valores de heterozigosidade e polimorfismo encontrados para espécies tropicais equiparam-se aos encontrados para a espécie aqui estudada, como Carapa guianensis com uma heterozigose de 0,12 e P 35\% (Hall et al., 1994). Entretanto, em comparação com dados de outras espécies de árvores tropicais, a diversidade total de Bertholletia excelsa foi um pouco abaixo dos valores encontrados, mas está dentro dos valores obtidos por Hamrick \& Loveless (1989) para espécies raras. Das 16 espécies analisadas pelos autores citados, 10 espécies tiveram valores muito próximos ao encontrado em nosso estudo, e o valor médio da diversidade genética relatado para espécies perenes $(0,149)$ foi similar ao nossos para as subpopulações adultos $(0,133)$.

A diversidade encontrada por Chase et al. (1995) dentro de populações de Cordia aliodora $(0,127)$ também foi similar à encontrada neste estudo $(0,105-0,149)$. Este autor observa que os valores encontrados de diversidade dentro de populações é comparável aos valores encontrados em espécies polinizadas por animais $(0,167)$.

Esperava-se, inicialmente, que as progênies das subpopulações de Castanha do Brasil em pastagens apresentassem aumento de endogamia, uma vez que nestas áreas as árvores remanescentes encontram-se isolados de seu ambiente natural (floresta) o que, supostamente, tenderia a favorecer uma maior ocorrência de cruzamentos entre aparentados e/ou autofecundação. Entretanto, essa não foi a tendência apresentada pelos nossos dados. A única subpopulação que apresentou um pequeno grau de endogamia foi a subpopulação P2 (Tabela 12). 
Os dados obtidos nesse trabalho para os indices de diversidade não demonstra alterações no padrão da heterozigosidade, contudo as frequências alélicas de alguns locos estão um pouco alteradas. Assim, por ser a espécie de baixa variabilidade e polimorfismo, ao menos em isoenzimas, e apresentar alelos raros para duas das três subpopulações estudadas, vemos a importância das árvores remanescentes nas pastagens como elos mantenedores de diversidade.

\subsection{Tamanho Efetivo $\left(\hat{N}_{e}\right)$}

As Tabelas 13 e 14 mostra as estimativa obtidas do tamanho efetivo das três subpopulações de Bertholletia excelsa, para os dados de matrizes e progênies.

Tabela 13. Tamanho efetivo $\left(\hat{N}_{e}\right)$ e número de indivíduos $(N)$ de três subpopulações de Bertholletia excelsa, considerando dados de progênies.

\begin{tabular}{lcc}
\hline \multicolumn{1}{c}{ Subpopulações } & $\hat{N}_{e}$ & $N$ \\
\hline Floresta & 31,3 & 131 \\
Pastagem de 2 anos & 63,0 & 157 \\
Pastagem de 4 anos & 49,9 & 145 \\
Total & 48,0 & 433 \\
\hline
\end{tabular}

Os valores do tamanho efetivo $\left(\mathrm{N}_{\mathrm{e}}\right)$ obtido para as progênies foram bem menores que o numero de indivíduos amostrados (Tabela 13), todavia isso é esperado dado o parentesco entre plântulas das progênies. Segundo Perecin (2000) o $\mathrm{N}_{\mathrm{e}}$ é menor que o número de individuos na grande maioria dos casos, significando que a representatividade genética é menor quanto menor o $\mathrm{N}_{\mathrm{e}}$.

Vencovsky (1987) demonstra que em familias de meios irmãos o tamanho efetivo corresponde a $\mathrm{Ne}=4 \mathrm{~F}$ e, em famílias de irmãos completos $\mathrm{Ne}=2 \mathrm{~F}$, sendo $\mathrm{F} \circ$ numero de famílias. Ao aplicar essa expressão para as progênies de $B$. exce/sa obtemos: $\mathrm{Ne}=4 \times 10=40$ para meios irmãos e $\mathrm{Ne}=2 \times 10=20$ para irmãos completos.

O menor $\mathrm{N}_{\mathrm{e}}$ encontrado foi para floresta $(31,3)$, todavia, ele está mais próximo a família de meios irmãos do que de irmãos completos. Assim, pode-se dizer que a maioria dos cruzamentos resultam de cruzamentos com pais diferentes, mas um pequena porcentagem pode ser resultante de cruzamento biparental. 
As subpopulações em pastagens foram as que obtiveram os maiores $N_{e}$ indicando que as progênies enquadrarem-se totalmente a famílias de meios irmãos, sendo suas plântulas resultado de cruzamento com pais diferentes.

Tabela 16. Tamanho efetivo $\left(\hat{N}_{e}\right)$ e número de indivíduos $(N)$ de três subpopulações de Bertholletia excelsa, considerando dados dos indivíduos adultos. Piracicaba 2001.

\begin{tabular}{lcl}
\hline \multicolumn{1}{c}{ Subpopulações } & $\hat{N}_{e}$ & $N$ \\
\hline Floresta & 42,1 & 30 \\
Pastagem de 2 anos & 29,3 & 30 \\
Pastagem de 4 anos & 34,0 & 30 \\
\hline Total & 105,4 & 90 \\
\hline
\end{tabular}

Pode-se observar que o tamanho efetivo para dados de adultos (Tabela 14) iguala-se, praticamente, ao número amostrado. Isso indica baixo parentesco entre esses indivíduos, sendo necessário um número de indivíduo igual ou maior que o $\mathrm{N}$ amostrado para conter a variabilidade genética da espécie.

Análises realizadas por diversos autores sobre estocasticidade genética resultaram em números de tamanho efetivo (50 e 500) e são usados amplamente nas definições de tamanho de reserva genética (Kageyama \& Lepsch-Cunha 2001). Segundo os diversos autores:

- $\mathrm{Ne}=50$ refere-se a uma população mínima viável efetiva de 50 indivíduos, que supostamente são suficientes para conter os efeitos de endogamia nas populações em 100 gerações.

- $\quad \mathrm{Ne}=500$ refere-se ao número mínimo viável de individuos efetivamente reprodutivos, suficientes para conter a perda da variabilidade genética, ao longo de 100 gerações, em populações sujeitas à ação de estocásticas.

Dessa forma, se conciliarmos a densidade média de indivíduos reprodutivos de $B$. excelsa por hectare, com o tamanho de uma população mínima viável proposto pelos diversos autores, pode-se predizer um tamanho mínimo de uma reserva para conservação da espécie. Assim, estabelecendo a ocorrência de um indivíduo $B$. excelsa por hectare, o tamanho $\mathrm{Ne}=50$ e $\mathrm{Ne}=500$ seriam 150 ha e 1.500 ha, respectivamente. 
Para efeito de conservação, O'Malley et al., (1988) sugeriram que, áreas que contém populações de $B$. excelsa, necessitam ser grandes em função do extenso fluxo gênico, o que possibilita maior cruzamento e favorece surgimento de uma maior variação genética. Considerando que o fluxo de pólen de $B$. excelsa é de longa distancia e que a dispersão de seus frutos de média a curta, pode ser mais eficiente para manutenção da diversidade da espécie, manter diversas áreas naturais de floresta com 150 ha e de 1500 ha. Pode-se predizer que, conservando várias áreas de 1.500 ha sem intervenção de fragmentação seja suficiente para garantir um tamanho mínimo viável para manutenção da diversidade genética da espécie por um periodo a longo prazo.

\subsection{Conservação e manejo de Bertholletia excelsa}

Os recursos das florestas tropicais tradicionalmente têm sido divididos em dois grupos principais: produtos madeireiros que incluem toras e polpa madeireira e produtos não madeireiros, que incluem óleos, látex, fibras, plantas medicinais e frutos comestíveis. A utilização de $B$. excelsa, atualmente, enquadra-se nesse ultimo grupo, e vale ressaltar sua notável importância para as comunidades tradicionais que vivem nas reservas extrativistas e projetos de assentamento na parte oriental do Estado do Acre e, de modo geral, na Amazônia.

$\mathrm{Na}$ amostragem realizada neste estudo verificou-se baixa divergência e maiores niveis de diversidade dentro das subpopulações. A baixa divergência entre as subpopulações aqui estudadas, indica ser apenas uma e, corrobora o encontrado por Buckley et al. (1988), onde a maior parte da diversidade encontra-se dentro das populações. Assim, esforços de coleta para produção de mudas ou para conservação exsitu pode ser feito por meio da amostra em vários indivíduos em poucas populações. Podese considerar que o baixo valor estimado para o coeficiente de endogamia apresentado não constitui um fator limitante para conservação in-situ, caso esse nivel seja mantido. Todavia, por se tratar de áreas com intervenções humanas, é provável que dentro de mais alguns anos o nivel de endogamia nas progênies aumente. Para conservação ex-situ, a amostragem precisa ser realizada de forma cuidadosa, uma vez que detectou-se alterações nas freqüências alélicas na geração progênies, as mesmas podem não representar muito bem a espécie. O ideal é que a amostragem seja feita em áreas que não 
sofreram ou tenham proximidade com intensas perturbações, como no caso de populações inseridas em Reservas Extrativistas.

A taxa de cruzamento, nos três ambientes estudados, mesmo sob pressão da fragmentação, manteve-se inalterada. Bertholletia excelsa pertence a um gênero monotípico $e$ investe muita energia para produção de flores e frutos com revestimento lenhosos. Assim, não é vantajoso para a espécie manter um sistema de cruzamento muito flexivel ou até mesmo misto, o que tenderia à maiores niveis de endogamia e, possivelmente, uma redução em sua variabilidade genética. Desta forma, é compreensivel que remanescentes em pastagens produzam menor quantidade de frutos por árvores, devido a ação de um sistema de auto-incompatibilidade, sendo mais vantajoso ter uma menor quantidade de frutos por árvores a ter um maior quantidade de frutos endogâmicos.

A presença de alelos raros, nas matrizes, para duas das três subpopulações estudadas, floresta e P2, demonstra a importância dos mesmos como elos mantenedores da diversidade, pois contribuem para incremento e manutenção da diversidade genética na espécie. Desta forma, é importante a conservação dos remanescentes por meio de um manejo adequado.

A presença de alelos raros, nas matrizes, para duas das três subpopulações estudadas, floresta e P2, demonstra a importância dos mesmos como elos mantenedores da diversidade por contribuírem ao incremento e manutenção da diversidade genética na espécie. É provável que dentro de mais seis anos as árvores remanescentes da P2 estarão todas mortas e um alelo raro será perdido. Desta forma, é importante a conservação dos remanescentes por meio de um manejo adequado,

A distribuição de $B$. excelsa no Estado do Acre limita-se na porção oriental e, é justamente nessa região que tem ocorrido a maior parte do desmatamento para colonização dos centros urbanos e desenvolvimento de cultura agrícolas ou agropecuárias.

As árvores remanescentes de Bertholletia excelsa nas duas idades de pastagens estudadas sofrem com alterações ambientais e uso do fogo. Os troncos de remanescentes queimados a cerca de 20 a $30 \mathrm{~m}$ de altura exudam resina frequentemente de seus troncos. Viana (no prelo) atribui a morte dos remanescentes ao uso do fogo. Constatou em áreas de pastagens, que a mortalidade das remanescentes é gradativa a medida que aumenta a idade de formação da pastagem. 
O resultado da análise de combustão da resina da espécie apresentou teor de combustibilidade de 5.466,80 PCS (Poder Calorifico Superior em Kcal/Kg) (Anexo 2). O teor de combustibilidade da resina do eucalipto é de 4.100 PCS, e é considerada altamente combustivel. O teor de combustibilidade de B. excelsa é cerca de 1.300 PCS a mais que do eucalipto. Assim, pode-se entender a trágica morte das remanescente em prazos tão curtos, como levantado por Viana (no prelo).

Como já foi mencionado anteriormente, não existe lei que garante a conservação das árvores remanescentes de Castanha do Brasil pós desmatamento. A portaria 449, proíbe o desmatamento em áreas de maciço da espécie, todavia isso não é cumprido. Desta forma, sugere-se como manejo, que a fragmentação de florestas com ocorrência da espécie deva ter prioridade de planejamento, visando garantir um ambiente similar ao proporcionado para a espécie em seu ambiente natural. Assim, ao fragmentar essas áreas, uma sugestão mínima que pode ser adotada é um planejamento onde se deixe a vegetação natural ao redor da(s) população(ões) da espécie, sendo essa vegetação, não por árvore remanescente, mas sim por agrupamentos (reboleiras) de remanescentes. Para dar conectividade entre esses agrupamentos e a floresta é essencial que seja deixado corredores ecológicos para manutenção de fluxo gênico. Essa sugestão na visa substituir a portaria 449, mas sim amenizar os efeitos do manejo em áreas de ocorrência da espécie ao serem fragmentadas.

Para efeito de conservação, os resultados do tamanho efetivo sugere que seja mantidas diversas áreas naturais de floresta com 150 ha e de 1500 ha. Pode-se predizer que conservando várias áreas de 1.500 ha, sem intervenção de fragmentação, seja suficiente para garantir um tamanho mínimo viável para manutenção da diversidade genética da espécie por um periodo a longo prazo.

Vale lembrar que as subpopulações em pastagens aqui estudadas estão relativamente próximas a floresta, quando comparada a situações de fragmentação de enormes extensões e distanciamento. Desta forma, em populações da espécie em áreas fragmentadas, com distancias maiores em relação a floresta, os dados estimados podem apresentar diferenças. 


\subsection{Sugestões Para Trabalhos Futuros com Bertholletia excelsa}

Estudo de populações em condições ambientais similares ao realizado nesse estudo com outros tipos de marcadores - microsatélite por exemplo. Pode ser mais informativo e ampliar a quantidade de locos polimórfico, além de poder confirmar alterações nas freqüências alélicas de uma geração à outra.

Avaliar a produção de frutos por árvore em floresta e em remanescentes em pastagens, para verificar se a diminuição da frutificação em remanescentes é inversamente proporcional a densidade por hectare.

Analisar fatores que possa estar contribuindo para diminuição da produção de frutos em remanescentes de $B$. excelsa em pastagens: i) nivel de danificação no tronco das remanescentes, pelo uso do fogo, que possa comprometer ramos da copa e culminar em menor quantidade de flores por árvores; ii) comparação da composição de insetos polinizadores entre floresta e pastagens; e iii) acompanhar o crescimento dos frutos em remanescentes em pastagens para verificar se ocorre aborto.

Fazer novas análise do teor de combustão da resina de Castanha do Brasil para árvores em pastagens e em floresta. No período de queimadas avaliar o teor de calor nos troncos das remanescentes.

Comparar taxa de sobrevivência e mortalidade de remanescentes de Castanha do Brasil em pastagens com e sem histórico de fogo por cerca de 10 anos.

Estudar populações remanescentes em pastagens com maiores distancias da floresta que as realizadas nesse estudo para efeito de comparação a taxa de cruzamento e ocorrência de fluxo de pólen. 


\section{CONCLUSÃO}

Ocorreu frutificação tanto na floresta como em vários remanescentes nas duas idades de pastagens.

Houve menor produção de frutos por árvores nos remanescentes em pastagens quando comparados com a floresta.

Os frutos produzidos em pastagens, apesar de viáveis, não contribuem para o incremento genético por não ter condições necessárias para regeneração e estabelecimento.

A espécie apresentou alelos raro para duas das três subpopulações estudadas: floresta e P2.

Foi encontrado baixa variabilidade e polimorfismo para espécie.

As três subpopulações estudadas podem ser considerada como uma apenas, devido a baixa divergência encontrada entre as mesmas.

A taxa de cruzamento foi alta para as três subpopulações, indicando que o sistema de cruzamento é predominantemente alógamo.

A baixa divergência encontrada entre as populações indica a ocorrência de fluxo gênico no passado. Atualmente, fluxo gênico é maior entre as duas idades de pastagens, intermediário entre floresta e P2 e menor entre floresta e P4.

As subpopulação floresta mostrou tamanho efetivo de adultos maior dos que as subpopulações em pastagens, sendo acima do número amostrado. Já o $N_{e}$ estimado nas progênies enquadram-se em famílias de meios irmãos.

O tamanho efetivo para dados de progênies estar dentro dos valores para familias de meios irmãos.

A resina de $B$. excelsa é altamente combustível. 
ANEXO 


\section{A1 - Sistema Isoenzimático desenvolvido Para Bertholletia excelsa}

Tabela 1. Composição da solução extratora de tecido foliar (Alfenas 1991). Piracicaba 2001.

\begin{tabular}{lc}
\multicolumn{1}{c}{ COMPOSTO } & QUANTIDADE \\
\hline Fosfato de sódio bibásico (0,034 M) & $0,6 \mathrm{~g}$ \\
Sacarose $(0,2 \mathrm{M})$ & $7,0 \mathrm{~g}$ \\
PVP-40 $(2,56 \%)$ & $2,56 \mathrm{~g}$ \\
L-ácido ascórbico & $100 \mathrm{mg}$ \\
DIECA (5,8 mM) & $100 \mathrm{mg}$ \\
Bissulfito de sódio (2,5 mM) & $50 \mathrm{mg}$ \\
Borato de sódio (2,5 mM) & $50 \mathrm{mg}$ \\
Polietilenoglicol-6000 (1\%) & $1,0 \mathrm{~g}$ \\
Água destilada (q.s.p.) & $100 \mathrm{ml}$ \\
\hline
\end{tabular}

Foram testados seis sistemas tampão cuba/gel, segundo Alfenas (1991) e Hillis (1996): Citrato morfolina (CM), Tris Borato - EDTA, Histidina, Tris Citrato, Tris Citrato Borato e Litium Borato.

Teste com 29 sistemas isoenzimáticos: álcool desidrogenase (ADH - EC 1.1.1.1), aldolase (ALD - EC 4.1.2.13), catalase (CAT - EC 1.11.1.6), diaforase (DIA - EC 1.8.1.4), enzima málica (ME - EC 1.1.1.40), esterase colorimétrica (EST - EC 3.1.1.1) método 2 e Esterase fluorescente que é o método 3, fosfatase ácida (ACP - EC 3.1.3.2), fofoglucomutase (PGM - EC 2.7.5.1), 6 fosfogluconato desidrogenase (6 PGDH - EC 1.1.1.44), fosfoglucose isomerse (PGI - EC 5.3.1.9), $\beta$ galactose desidrogenase (GLDH EC 1.1.1.48), gliceraldeído-3-fosfato desidrogenase (G3PDH - EC 1.2.1.12), glicerato-2 desidrogenase (G2DH - EC 1.1.129), glucose desidrogenase (GLUDH - EC 1.1.1.47), glucose-6-fosfato desidrogenase (G6PDH - EC 1.1.149), glutamato desidrogenase (GDH EC 1.4.1.3), glutamato-oxaloacetato transaminase (GOT - EC 2.6.1.1), isocitrato desidrogense (IDH - EC 1.1.1.42), lactato desidrogenase (LDH - EC 1.1.1.27), leucina aminopeptidadse (LAP - EC 3.4.11.1), malato desidrogenase (MDH - EC 1.1.1.37), manito desidrogenase (MADH - EC 1.1.1.67), nicotinamida adenina dinucleotídeo desidrogenase (NADHDH - EC 1.6.99.3), peroxidadse (PO - EC 1.11.1.7), sorbitol desidrogenase (SDH EC 1.1.1.14), superóxido dismutase (SOD - EC 1.15.1.1), xantina desidrogenase (XDH EC 1.2.1.37), xiquimato desidrogenase (SK - EC 1.1.1.25).

Após os testes, foram selecionados 2 sistemas cuba/gel e 10 sistemas enzimáticos, descritos a seguir:

CITRATO MORFOLINA pH 6,1 ( $7^{f}$ ) (Alfenas, 1991)

Tampão cuba:

Ácido cítrico $0,04 \mathrm{M}$ $8,4 \mathrm{~g}$

Água deionizada $1000 \mathrm{ml}$

Dissolver ácido cítrico em $800 \mathrm{ml}$ de água e titular com N (3 amino propil) morfolina até $\mathrm{pH} 6,1$, e completar para $1000 \mathrm{ml}$.

\section{Tampão do gel:}

Misturar $50 \mathrm{ml}$ do tampão de cuba com $950 \mathrm{ml}$ de água deionizada. 
Composição do gel

Amido

$34,29 \mathrm{~g}$

Penetrose

$18,29 \mathrm{~g}$

Sacarose

$12,00 \mathrm{~g}$

Tampão do gel

$400 \mathrm{ml}$

\section{O preparo do gel:}

A solução do gel era colocada por 15 minutos no agitador elétrico, em seguida, no forno microondas por 5 minutos com intervalo de 30 segundos para agitação manual. Após cozimento, o gel era colocado em placas de vidro para resfriamento.

1) Malato Desidrogenase (MDH - EC 1.1.1.37)

Ácido málico $0,5 \mathrm{M}, \mathrm{pH} 8,0$

$\mathrm{DL}$ - Ácido Málico $6,71 \mathrm{~g}$

Hidróxido de sódio $2,00 \mathrm{~g}$

Água destilada $100 \mathrm{ml}$

Colocar o Hidróxido de $\mathrm{Na}$ em um becker e levar a banho maria frio, e adicionar o Ácido málico e a água destilada e agite com um bastão de vidro. Ajuste o pH para $8,0 \mathrm{com} \mathrm{NaOH}$.

Coloração:

Ácido málico $0,5 \mathrm{M}, \mathrm{pH} 8,0 \quad 4 \mathrm{ml}$

Tris $\mathrm{Hcl}(0,1 \mathrm{M}) \mathrm{pH} 8,5 \quad 50 \mathrm{ml}$

MTT $1 \mathrm{ml}$

PMS $1 \mathrm{ml}$

NAD $1 \mathrm{ml}$

Procedimento: Misturar o substrato, solução e co-fatores e incubar no escuro $30^{\circ}-37^{\circ} \mathrm{C}$, por aproximadamente 15 a 60 minutos.

2) Fosfoglucose Isomerase (PGI - EC 5.3.1.9)

Frutose 6 fosfate

$30 \mathrm{mg}$

Tris $\mathrm{Hcl}(0,1 \mathrm{M}) \mathrm{pH} 8,0$

$50 \mathrm{ml}$

MTT

$1 \mathrm{ml}$

PMS

$1 \mathrm{ml}$

NADP

$1 \mathrm{ml}$

$\mathrm{MgCl}_{2}$

$1 \mathrm{ml}$

NAD

$1 \mathrm{ml}$ 
Glucose -6 -fosfato desidrogenase (G6PDH) $\quad 0,01 \mathrm{ml}$

Procedimento: Procedimento: Misturar o substrato, solução e co-fatores, adicionando a G6PDH por último. Incubar o gel no escuro a $30-37^{\circ} \mathrm{C}$ até as bandas aparecerem.

3) Esterase (EST - EC 3.1.1.1)

$\propto$ Naftil-acetato $\quad 40 \mathrm{mg}$

Fast garnet GBC $30 \mathrm{mg}$

Tampão Fosfato de $\mathrm{Na} 0,05 \mathrm{M} \mathrm{pH} \mathrm{6,0 \quad 50} \mathrm{ml}$

Acetona $50 \%$

Procedimento: Diluir o $\propto$ Naftil-acetato e o Fast garnet GBC em $1 \mathrm{ml}$ de acetona a $50 \%$ (separadamente). Em seguida adicionar a solução tampão e incubar o gel a $30-37^{\circ} \mathrm{C}$ até as bandas aparecerem (15 a 30 minutos).

4) Esterase Fluorescente (EST - EC 3.1.1.1) (FEST)

4 metil-umbeliferil acetato $5 \mathrm{mg}$

Tampão acetato de $\mathrm{Na} 0,2 \mathrm{M} \mathrm{pH} \mathrm{5,0}$ $10 \mathrm{ml}$

Acetona $50 \%$ $1 \mathrm{ml}$

Procedimento: Diluir o 4 metil-umbeliferil acetato em $1 \mathrm{ml}$ de acetona a $50 \%$ e adicionar a solução tampão. Coloque o gel sobre a suporte de ultravioleta e pincele a solução corante. Após 3 a 5 minutos pode visualizar as bandas fluorescentes rapidamente, devido a fugacidade.

5) Peroxidase (PO - EC 1.11.1.7)

O Dianisidina $\mathrm{bi}-\mathrm{HCl} \quad 30 \mathrm{mg}$

Acetato de $\mathrm{Na} 0,2 \mathrm{M} \mathrm{pH} 5,0 \quad 50 \mathrm{ml}$

Etanol

$1 \mathrm{ml}$

$\mathrm{H} 2 \mathrm{O} 2(50 \%)$

$1,5 \mathrm{ml}$

Procedimento: diluir a O Dianisidina bi $-\mathrm{HCl}$ em $1 \mathrm{ml}$ de etanol, adicionar o tampão e incubar o gel no escuro a $30-37^{\circ} \mathrm{C}$ por 30 minutos. Em seguida, retirar o gel da estufa e adicionar $1,5 \mathrm{ml}$ de $\mathrm{H} 2 \mathrm{O} 2(50 \%)$ e observe as bandas aparecerem.

Tris - Borato - EDTA ${ }^{2 b}$ (Alfenas, 1991 - modificado)

Tampão Cuba:

Trizma $0,18 \mathrm{M}$

Ácido Bórico $0,1 \mathrm{M}$

$6,18 \mathrm{~g}$

EDTA $0,032 \mathrm{M}$ $11,92 \mathrm{~g}$ 
Água deionizada $\quad 1000 \mathrm{ml}$ completar até $1000 \mathrm{ml}$.

Dissolver os reagentes em $800 \mathrm{ml}$ de água e acertar o pH 8,0 com $\mathrm{NaOH}$,

Tampão Gel:

Trizma $0,18 \mathrm{M} \quad 21,80 \mathrm{~g}$

Ácido Bórico $0,1 \mathrm{M} \quad 6,18 \mathrm{~g}$

EDTA $0,032 \mathrm{M} \quad 11,92 \mathrm{~g}$

Água deionizada $\quad 1000 \mathrm{ml}$

completar até $1000 \mathrm{ml}$.

Dissolver os reagentes em $800 \mathrm{ml}$ de água e acertar o $\mathrm{pH} 8,0 \mathrm{com} \mathrm{NaOH}$,

Diluir o tampão em 1:4 de água deionizada para o uso.

\section{Composição do $\mathrm{Gel}$}

Amido

$34,29 \mathrm{~g}$

Penetrose

$18,29 \mathrm{~g}$

Sacarose

$12,00 \mathrm{~g}$

Tampão do gel

$400 \mathrm{ml}$

O procedimento de preparo do gel é o mesmo do Citrato morfolina

6) Xiquimato Desidrogenase (SKDH - EC 1.1.125)

$\begin{array}{lr}\text { Acido Xiquímico } & 80 \mathrm{mg} \\ \text { Tris - } \mathrm{Hcl} 0,1 \mathrm{M} \mathrm{pH} 8,5 & 50 \mathrm{ml} \\ \text { MTT } & 1 \mathrm{ml} \\ \text { PMS } & 1 \mathrm{ml} \\ \text { NADP } & 1 \mathrm{ml}\end{array}$

Procedimento: Misturar o substrato, solução tampão e co-fatores e incubar no escuro a $30^{\circ}-37^{\circ} \mathrm{C}$, por aproximadamente 60 minutos.

7) Leucina Aminopeptidase (LAP EC - 3.4.11.1)

L - Leucina - $\beta$ - Naftilamida - $\mathrm{HCl} \quad 40 \mathrm{mg}$

Fast black $\mathrm{K}$ salt $\quad 50 \mathrm{mg}$

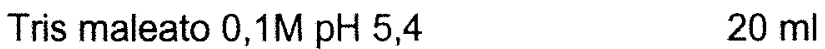

Água destilada $\quad 30 \mathrm{ml}$

Metanol (30\%) $1 \mathrm{ml}$ 
Procedimento: Diluir a L Leucina - $\beta$ - Naftilamida - $\mathrm{HCl}$ e o Fast black $\mathrm{K}$ salt (separadamente) em $1 \mathrm{ml}$ de metanol a $30 \%$. Em seguida adicionar a solução tampão e a água destilada. Incube no escuro a $30^{\circ} \mathrm{C}$

8) 6 Fosfogluconato Desidrogenase (6PGDH - EC 1.1.1.44)

$\begin{array}{lr}\text { Ácido } 6 \text { - fosfoglucônico, } \mathrm{Na}_{3} & 30 \mathrm{mg} \\ \text { Tris - } \mathrm{HCl} \mathrm{0,1M} \mathrm{pH} \mathrm{8,0} & 50 \mathrm{ml} \\ \text { MTT } & 1 \mathrm{ml} \\ \text { PMS } & 1 \mathrm{ml} \\ \text { NADP } & 1 \mathrm{ml} \\ \mathrm{MgCl}^{2} & 1 \mathrm{ml}\end{array}$

Procedimento: : Misturar o substrato, solução tampão e co-fatores e incubar no escuro a $30^{\circ}-37^{\circ} \mathrm{C}$, por aproximadamente 60 minutos.

9) Glucose 6 Fosfato Desidrogenase (G6PDH - EC 1.1.1.49)

$\begin{array}{lr}\text { Glucose-6-fosfato } & 110 \mathrm{mg} \\ \text { Tris } \mathrm{Hcl}(0,2 \mathrm{M}) \mathrm{pH} 8,0 & 50 \mathrm{ml} \\ \text { MTT } & 1 \mathrm{ml} \\ \text { PMS } & 1 \mathrm{ml} \\ \text { NADP } & 1 \mathrm{ml} \\ \mathrm{MgCl}^{2} & 1 \mathrm{ml}\end{array}$

Procedimento: : Misturar o substrato, solução tampão e co-fatores e incubar no escuro a $30^{\circ}-37^{\circ} \mathrm{C}$, por aproximadamente 60 minutos.

10) Diaforase (DIA - EC 1.8.1.4)

$\mathrm{NADH}$

2,6 diclorofenol-indofenol

Tris - $\mathrm{HCl} 0,05 \mathrm{M} \mathrm{pH} \mathrm{8,0}$

MTT

$$
\begin{gathered}
15 \mathrm{mg} \\
1 \mathrm{mg} \\
50 \mathrm{ml} \\
1 \mathrm{ml}
\end{gathered}
$$

Procedimento: Misturar o substrato, solução tampão e co-fatores e incubar no escuro a $30^{\circ}-37^{\circ} \mathrm{C}$, por aproximadamente 60 minutos. 
A2 - Resultado da análise de combustão da resina de Bertholletia excelsa

Resultado da análise de combustão da resina de Castanha do Brasil (Bertholletia excelsa) realizado no Departamento de Ciências Florestais da Escola Superior de Agricultura "Luís de Queiroz".

\% ET 26.52

$\mathrm{PCS}(\mathrm{Kcal} / \mathrm{Kg}) \quad 5.466,80$

OBS:

$\% \mathrm{ET}=$ Teor Extrativos totais

$\mathrm{PCS}=(\mathrm{Kcal} / \mathrm{Kg})=$ Poder Calorífico Superior

PS! A resina do eucalipto tem poder calorífico de aproximadamente $4.100,00$ 


\section{REFERÊNCIAS BIBLIOGRÁFICAS}

ACRE. Secretaria do Meio Ambiente. Atlas geográfico ambiental do acre. Rio Branco, 1991. 48p.

AGENNCIA DE COOPERAÇÃO INTERNACIONAL DO JAPÃO. For our green earth. Tokyo: JICA, 1993. 27p.

AGUIAR-PARECIN, M.L.R.; MARTINS, P.S.; BANDEL, G. Colóquio sobre a citogenética e evolução de plantas. Piracicaba: Sociedade Brasileira de Genética, 1984. 240 p.

ALFENAS, A.C.; PETERS I.; BRUNE W. et al. Eletroforese de proteínas e isoenzimas de fungos e essências florestais. Viçosa: SIF, 1991. 242p.

ALLEGRETTI, M.A. Reservas extrativistas: uma proposta de desenvolvimento da floresta amazônica. Pará Desenvolvimento, n. 25, p.3-29, jan/dez. 1989.

ALMEIDA, C.P. Castanha do Pará: sua exportação e importância na economia Amazônica. Rio de Janeiro: Ministério da Agricultura, Serviço de Informação Agrícola, 1963. 84p. (Estudos Brasileiros, 13)

BAIDER, C. Demografia e ecologia de dispersão de frutos de Bertholletia excelsa Humb. \& Bonpl. (Lecythidaceae) em castanhais silvestres da Amazônia Oriental. São Paulo, 2000. 231p. Tese (Doutorado) - Instituto de Biociências, Universidade de São Paulo.

BARTON, N.H.; SLATKIN, M.A. Quase-equilibrium theory of the distribution of alleles in a subdivided population. Heredity, v. 56, p.409-415, 1985.

BAWA, K.S. Breeding systems of tree species of a lowland tropical community. Evolution, v.28, p.85-92, 1974.

BAWA, K.S.; O'MALLEY, D.M. Estudios genéticos y de sistemas de cruzamiento en algunas especies arbóreas de bosques tropicales. Revista de Biologia Tropical, v.35, supl. 1, p.177-188, 1987.

BAWA, K.S. Mating systems, genetic differentiation and speciation in tropical rain forest plants. Biotropica, v.24, n.2b, p.250-255, 1992.

BENTES, R. S.; MARIN, R.A.; EMMI, M.F. Os cemitérios das castanheiras do Tocantins. Pará Desenvolvimento, n.23, p.18-23, jan./jun. 1988. 
BOSHIER, D.H.; CHASE, M.R.; BAWA, K. Population genetics of Cordia alliodora (Boraginaceae), a neotropical tree. 2. Mating system. American Journal of Botany. Journal of Botany, v.82, n.4, p.476-483, 1995.

BROWN, A.H.D. Genetic characterization of plant mating systems. In: BROWN, A.H.D.: CLEGG, M.T.; KAHLER, A.L. et al. (Ed.) Plant population genetics, breeding, and genetic resources. Sunderland: Sinaeur Associates, 1990. p. 145-162.

BROWN Jr., K.S.; BROWN, G.G. Habitat alteration and species loss in Brazilian forests. In: WHITMORE, T.C.; SAYER, J.A. Tropical deforestation and species extinction. New York: Chapman and Hall, 1994. p.119-142.

BRUNE, A. Reproductive biology and tropical plantation forestry. In: BAWA, S.; HADLEY M. (Ed.) Reproductive ecology of tropical forest plants. Paris: UNESCO, 1990. cap. 24, p. 349-354. (Man and Biosphere Series, 7)

BUCKLEY, D.P.; O'MALLEY D.M.; APSIT V. et al. Genetics of Brazil nut (Bertholletia excelsa Humb. \& Bonpl.:Lecythidaceae. 1. Genetic variation in natural populations. Theoretical and Applied Genetics, v.76, p.923-928, 1988.

BULLOCK, S.H. Breeding system in the flora of a tropical a deciduos forest in Mexico. Biotropica, v.17, n.4, p.287-301, 1985.

CAMARGO, P.B. de; SALOMÃO, R.P.; TRUMBORE, S. et al. How old are large BrazilNut trees (Bertholletia execelsa) in the Amazon? Scientia Agricola, v.51, n.2, p.389-391, maio/ago. 1994.

CAVALCANTE, P.B. Frutas comestíveis da Amazônia. 4.ed. Belém: Museu Paraense Emílio Goeldi; Companhia Souza Cruz Industria e Comércio, 1988. 279 p. (Coleção Adolpho Ducke)

CGIAR. Keeping faith with the future: forests and their genetic resources. Rome: Di Leo, 1994. 14p.

CHASE, M.R.; BOSHIER, D.H.; BAWA, K. Population genetics of Cordia alliodora (Boraginaceae), a neotropical tree. 1. Genetic variation in natural population. American Journal of Botany, v.82, n.4, p.468-475, 1995.

CLEGG, M.T. Measuring plant mating systems. Bioscience, v.30, n.12, p.81-818, 1980.

COCKERHAM, C.C. Variance of gene frequencies. Evolution, v.23, n.1, p.72-84, 1969.

COCKERHAM, C.C; WEIR, B.S. Estimation of gene flow from F-Statistics. Evolution, v.47 n.3, p.885-863, 1993.

DAFNI, A. Pollination ecology: a practical approach. New York: Oxford University Press, 1992. 186p. 
DEUS, C.E. de; BUENO,C.S.C.; NOGUEIRA, M.C.G. Conservação dos Recursos Naturais do Estado do Acre. Silvicultura em São Paulo, v.16a, n. 3. p.1551-1567, 1982.

DICK, W.C. Genetic rescue of remnant tropical trees by an alien pollinator. Proc. Roy Acad. London, 2001. /No prelo/

ELLSTRAND, N.C.; ELAN, D.R. Population genetic consequences of small population size: Implications for plant conservation. Annual Review of Ecology and Systematic, v.24, p. 217-242, 1993.

FAEGRI, K.; VAN DER PIJL, L. The principles of pollination ecology. London: Pergamon Press, 1979. 244p.

FORÉ, S.A.; HICKEY, R.J.; VANKAT, J.L. et al. Genetic structure after forest fragmentation: an landscape ecology perspective on Acer saccharum. Canadian Journal of Botany, v.70, p.165-168, 1992.

FUNDAÇÃO TECNOLÓGICA DO ESTADO DO ACRE. Atlas educativo do acre. Rio Branco, 1990. 47p.

FUTUYMA, D.J. Biologia evolutiva. Ribeirão Preto: Sociedade Brasileira de Genética; CNPq, $1992.646 \mathrm{p}$.

GANDARA, F. B. Diversidade genética e taxa de cruzamento em uma população de Cedrela fissilis Vell. (Meliaceae). Piracicaba, 1995. 69p. Dissertação (Mestrado) Escola Superior de Agricultura "Luís de Queiroz", Universidade de São Paulo.

GOVINDARAJU, D.R. A note on the relationship between out-crossing rate and gene flow in plants. Heredity, v.61, p.401-404, 1988a.

GOVINDARAJU, D.R. Relationship between dispersal ability and levels of gene flow in plants. Oikos, v.52, p.31-35, $1988 \mathrm{~b}$.

HALL, P.; ORRELL, L.C.; BAWA, K. Genetic and mating system in a tropical tree, Carapa guianensis (Meliaceae). America Journal of Botany, v.81, n.9, p.11041111, 1994.

HAMRICK, J.L. The distribution of genetic variation within and among natural plant population. In: SCHONEWALD-COX, C.M.; CHAMBERS, S.M.; MACBRYDE, B. et al. (Ed.) Genetics and conservation: a reference for managing wild animal and plant populations. Menlo Park: Benjamin Cummings Publ., 1983. p.335-348.

HAMRICK, J.L.; GODT, M.J.W. Allozyme diversity in plant species. In: BROWN, A.H.D.: CLEGG, M.T.; KAHLER, A.L. et al. (Ed.) Plant population genetics, breeding, and genetic resources. Sunderland: Sinauer Associates, 1990. p.145162. 
HAMRICK, J.L. Gene flow and distribution of genetic variation in plant populations. In: Differentiation patterns in higher plants. New York: Academic Press, 1987. p. 5367.

HAMRICK, J.L.; MURAWSKI, D.A. Levels of allozyme diversity in populations of uncommom Neotropical tree species. Journal of Tropical Ecology, v.7, p.395-399, 1991.

HAMRICK, J.L.; LINHART, Y.B.; MITTON, J.B. Relationships between life history characteristics and electrophoretically detectable genetic variation in plants. Annual Review of Ecology Systematics, v.10, p.173-200, 1979.

HILLIS, D.M.; MORITZ, C.; MABLE, B.K. Molecular systematics. Sunderland: Sinauer Associates, $1996.405 \mathrm{p}$.

JANZEN, D. H. Euglossine bees as long-distance pollinators of tropical plants. Science, v.171, p.203-205, 1971.

JANZEN, D. H. Ecologia vegetal nos trópicos. São Paulo: EPU; EDUSP, 1980. 79p.

KAGEYAMA, P.Y. Conservação "in situ' de Recursos Genéticos de Plantas. Silvicultura, v.11, n.41, p.7-37, 1986.

KAGEYAMA, P.Y. Genetic struture of tropical tree species of Brazil. In: BAWA, K.S.; HADLEY, M. Reprodutive ecology of tropical forest plants. Paris: UNESCO, 1990. cap.26. p.375-387. (Man and Biosphere Series, 7)

KAGEYAMA, P.Y.; GANDARA, F.B. Dinâmica de populações de espécies arbóreas: implicações para o manejo e a conservação. In: SIMPÓSIO DE ECOSSISTEMAS DA COSTA BRASILEIRA, 3, Serra Negra, 1993. Anais. São Paulo: Academia de Ciências do Estado de São Paulo, 1993. p.1-4.

KAGEYAMA, P.Y.; LEPCH-CUNHA, N. Singularidade da biodiversidade nos trópicos. In: GARAY, I.; DIAS, B.; EXCELSA, F.S. Conservação da biodiversidade em ecossistemas tropicais. Petrópolis: Vozes, 2001, p.199-214.

KAINER, K.A. Enrichment prospects for extractive reserve in a nutshell: Brazil nut germination and seedling autoecology in Brazilian Amazon. Gainesville, 1999. 119p. Thesis (Ph.D) - University of Florida.

KITAMURA, P.C.; MULLER C.H. Castanhais nativos de Marabá - PA: fatores de depredação e bases para sua preservação. Belém: EMBRAPA, CPATU, 1984. 32p. (EMBRAPA.CPATU. Documentos, 30)

LACERDA, C.M.B.; KAGEYAMA, P.Y.; FERRAZ, E.M. Diversidade isoenzimática em Myracrodruom urundeuva em duas situações antrópicas no semi-arido. Scientia florestalis, n.55, p.89-96, Junho 1999. 
LAURANCE, W.F. A crisis in the making: responses of Amazonian forests to land use and climate change. Trends in Ecology and Evolution, v.13, n.10, p. 411-415, 1998.

LEITÃO-FILHO, H.F. Considerações sobre a florística de florestas tropicais e subtropicais de Brasil: IPEF, v.35, p.41-46, abr. 1987.

LEPSCH-CUNHA, N. Estrutura genética e fenologia de espécies raras de Couratari spp. (Lecythidaceae) na Amazônia Central. Piracicaba, 1996. 147p. Dissertação (Mestrado) - Escola Superior de Agricultura "Luis de Queiroz", Universidade de São Paulo.

LEVIN, D.A. Dispersal versus gene flow in plants. Annals of the Missouri Botanical Garden, v.68, p.233-253, 1981.

LEWIS, P.; ZAYKIN, D. Genetic data analysis: versão 1 para windows 3.1. 1999. (não publicado).

LI, C.C. Population genetics.. Pacific Grower, The Boxwood Press, 1976. 631 p.

LOPES, M DE R. Estudo da castanha do Brasil. Brasília: Ministério da Agricultura: Comissão de Financiamento da Produção, 1972. 62p.

LORENZI, H. Árvores brasileiras: manual de identificação e cultivo de plantas arbóreas nativas do Brasil. Nova Odessa Plantarum, 1992. 353p.

MARTINS, P.S. Estrutura populacional, fluxo gênico e conservação "in situ". IPEF, n.35, p.71-78, 1987.

MAUÉS, M.M.; OLIVEIRA, F.C. Fenologia reprodutiva e etnofauna polinizadora da Castanheira-do-Brasil (Bertholletia excelsa Hump. \& Bonpl. Lecythidadceae) na Amazônia Oriental. Embrapa-CPATU, Documentos n.123, p.25-30, 1999.

MAY, B.. Starch gel electrophoresis of allozymes. In: HOELZEL A. R. Molecular genetic analysis of populations: a practical approach. New York: Oxford University Press, 1992. cap. 1, p.1-27.

MORI, S.A.; PRANCE, G.T. Relações entre a classificação genérica de Lecythidaceae do Novo Mundo e seus polinizadores e dispersores. Revista Brasileira de Botânica, v.4, p.31-37, 1981.

MORI, S.A.; PRANCE, G.T. Species diversity, phenology, plant-animal interactions, and their correlation with climate, as illustrated by the Brazil nut family (Lecythidaceae). In: DICKINSON, R.E. (Ed.) The geophysiology of Amazonia. New York: John Wiley, 1987. p. 69-89.

MORI, S.A.; PRANCE, G.T. Flora neotropica: Lecythidaceae - Part II. New York: Botanical Garden, 1990a 125p. (Monograph, 21). 
MORI, S.A.; PRANCE, G.T. Taxonomy, ecology and economic botany of Brazil nut (Bertholletia exce/sa Humpl. And Bonpl.: Lecythidaceae). Advances in Economic Botany, v.8, p.130-150, 1990b.

MORITZ, A. Estudos biológicos da floração e da frutificação da Castanha-do-Brasil Bertholletia excelsa H.B.K.). EMBRAPA: Centro de pesquisa Agropecuário do Trópico Úmido. Documentos n.29, p.1-82, 1984.

MÜLLER, C.H. Quebra da dormência da semente e enxertia em castanha - do - Brasil. Belém: EMBRAPA, CPATU, 1982. 40p. (EMBRAPA. CPATU. Documentos, 16)

MULLER, C.H.; FIGUEREDO, F.J.C. Profundidade e posição de semeadura de sementes de castanha do Brasil. Belém: EMBRAPA, CPATU, 1991. 18p. (EMBRAPA. CPATU. Circular Técnica, 62)

MULLER, C.H.; FIGUEREDO, F.J.C.; KATO, A.K. A cultura da castanha-do-brasil. Brasília: EMBRAPA, Centro de Pesquisa Agroflorestal da Amazônia Oriental, 1995. $65 p$.

MULLER, C.H.; RODRIGUES, I.A.; MULLER, A.A. et al. Castanha do Brasil: resultados de pesquisa. Belém: EMBRAPA, CPATU, 1980. 25 p. (Miscelânea, 2).

MURAWSKI, D. A. DAYANANDAN, B.; BAWA, K.S. "Outcrossing rates of two endemic Shorea species from Sri Lankan tropical rain forest". Biotropica, v.26, n.1, p.23-29, 1994.

NEGRÃO, M.O. Estrutura genética de populações naturais de Syagrus romanzofiana (Arecaceae) do continente (Serra do mar, S.P.) e da ilha dos alcatrazes. Piracicaba, 1999. 80p. Dissertação (Mestrado) - Escola Superior de Agricultura "Luiz de Queiroz", Universidade de São Paulo .

NEI, M.; MARUYAMA, T.; CHAKRABORTY, R. The bottleneck effect and genetic variability in populations. Evolution, v.29, p.1-10, 1975.

NELSON, B.W.; ABSY M.L.; BARBOSA E.M.; PRANCE G.T. Observations on flower visitors to Bertholletia excelsa H.B.K. and Couratari tenuicarpa A.C.SM. (Lecythidaceae). Acta Amazônica, v.1/2, supl. 5, p.225-234, 1985.

NEVES, C.A. A castanheira do Pará. Revista de Agricultura, v. 13, n.1/2, p.463-476, 1938

OLIVEIRA, A.A. Diversidade, estrutura e dinâmica do componente arbóreo de uma floresta de terra firme de Manaus, Amazonas. São Paulo, 1997. 187p. Tese (Doutorado) - Instituto de Biociências, Universidade de São Paulo.

O'MALLEY, D.M.; BUCKLEY D.P.; PRANCE G.T. et al. Genetics of Brazil nut (Bertholletia excelsa Humb. \& Bonpl.: Lecythidaceae). 2. Mating system Theoretical and Applied Genetics, v.76, p.929-932, 1988. 
PERECIN, B. Diversidade genética em populações naturais de espécies de espinheirasanta, Maytenus aquifolia Mart. e M. ilicifolia Mart. ex Reiss. Piracicaba, 2000. 134p. Tese (Doutorado) - Escola Superior de Agricultura "Luis de Queiroz", Universidade de São Paulo.

PINHEIRO, E.; ALBUQUERQUE, M. Castanha do Pará. in Brasil. In: BRASIL. Ministério de Agricultura. Livro anual da agricultura. Brasília, 1968. p.225-233.

PRANCE, G.T. The pollination and androphore structure of some amazonian Lecythidaceae. Biotropica, v.8, n.4, p.235-241, 1976.

PRANCE, G.T.; MORI, S. A. Lecythidaceae. Flora Neotropica, v.1, n.21, p.1-270, 1978.

RAMALHO, M.; SANTOS, J.B. dos; PINTO, C.B. Genética na agropecuária. São Paulo: Globo, 1995. 359p.

REIS, M.S. dos. Dinâmica da movimentação dos alelos: subsídios para conservação e manejo de populações naturais em plantas. Brazilian Journal of Genetics, v. 19, supl. 4, p.37-47, 1996.

RICHARDS, A.J. Plant breeding systems. London: Allen \& Unwin, 1986. 287p.

RIJSOORT, J.V.; UGUETO, S.; ZUIDEMA, P. The Brazil Nut tree (Bertholletia excelsa): populations structures in tropical rain forest and growth response of seedlings to different light intensities. Madre de Dios: Department of Plant Ecology and Evolutionary Biology, 1993. 58p.

RITLAND, $K$ A series of fortran computer programs for estimating plant mating systems. Journal of Heredity, v. 81, p.235-237, 1990.

RITLAND, K. Multilocus Mating System Program MLTR: version 1.1. Toronto: University of Toronto, 1997. (não publicado).

ROBINSON, I.P. Aloenzima na genética de populações de plantas. In: ALFENAS, A.C. Eletroforese de isoenzimas e proteínas afins; fundamentos e aplicações em plantas e microorganismos. Viçosa: Editora UFV, 1998. cap.7, p.329-380.

SALOMÃO, R.P. Estrutura e densidade de Bertholletia exce/sa H. \& B (Castanheira) nas regiōes de Carajás e Marabá, Estado do Pará. Mus. Para. Emilio Goeldi, ser. Bot. 7(1). 1991. 14p.

SEBBEN, A.M.; KAGEYAMA, P.Y.; VENCOVSKY, R. Variabilidade genética, sistema reprodutivo e estrutura genética espacial em Genipa americana L. através de marcadores isoenzimáticos. Scientia florestalis, n. 53, p.15-30, jun. 1998.

SEOANE, C.E.S. Efeitos da fragmentação sobre a estrutura genética de populações de Esenbeckia leiocarpa Engl. - guarantã - um exemplo de uma espécie arbórea 
tropical climácica de distribuição agregada. Campinas, 1998. 80p. Tese (Mestrado) - Universidade de Campinas.

SEOANE, C.E.S.; KAGEYAMA, P.Y.; SEBBEN, A.M. Efeitos da fragmentação florestal na estrutura genética de Esenbeckia leiocarpa Engl. (Guarantã). Scientia florestalis, n. 57 , p. 123-139, jun. 2000.

SHANLEY, P.; CYMERYS, M.; GALVÃO J. Frutíferas da mata na vida amazônica. Belém: s.ed., 1998. 127p.

SLATKIN, M. Estimating levels of gene flow in natural population. Genetics, v.99, p. 323-335, 1981.

SOUZA, A.H. de. Castanha do Pará: estudos botânico, químico e tecnológico. Rio de Janeiro: Ministério da Agricultura, Serviço de Informação Agrícola, 1963. 69p. (Estudos Técnicos, 23).

SOUZA, L.M.F.I. Estrutura genética de populações naturais de Chorisia speciosa St. Hil (Bombacaceae) em fragmentos florestais na região de Bauru (SP) - Brasil. Piracicaba, 1997. 76p. Dissertação (Mestrado) - Escola Superior de Agricultura "Luiz de Queiroz", Universidade de São Paulo.

STACY, E.A. HMARICK, J.L.; NASON J.D. et al. Pollen dispersal in low density populations of three neotropical tree species. American Nature, n. 148, p.275-298. 1996.

SWOFFORD, D.L.; SELANDER, R.B. Biosys-1.: a computer program for the analysis of allelic variation in population genetics and biochemical systematics; release 1.7. Illinois: Illinois History Survey, 1989

VENCOVSKY, R. Tamanho efetivo populacional na coleta e preservação de germoplasmas de espécies alógamas. IPEF, n.35, p.79-84, 1987.

VENCOVSKY, R. Análise de variância de frequências alélicas. Revista Brasileira de Genética, v.17, n. 3, p.349-351, 1992. Suplemento 1.

VIANA, V.M.; MELLO, R.A.; MORAES, L.M. de et al. Ecologia e manejo de populações de Castanha-do-Pará em reservas extrativistas Xapuri, Estado do Acre. In: GASCON, C.; MONTINHO, P. Floresta amazônica: dinâmica regeneração e manejo. Manaus: INPA, 1998. cap.18, p.277-292.

VIANA, V.M.; MELLO, R.A.; MORAES, L.M. de; et al. Deforestation, decay of brazil nut populations in pastures and forest policies in the Amazon: the case of Xapuri. Manuscrito.

TORGGLER, M.G.F.; CONTEL, E.P.B.; TORGGLER, S.P. Isoenzimas: variabilidade genética em plantas. Ribeirão Preto: Sociedade Brasileira de Genética. 1995. 186p. 
WEIR, B.S. Genetic data analysis: methods for discrete population genetic data. Sunderland: Sinauer Associates, 1990. 377p.

WILSON, E.O. Biodiversity. Washington: National Academy Press, 1988. 521p.

WRIGHT, S. Evolution in mendelian population. Genetics, v.16, p. 97-159, 1931.

WRIGHT, S. The interpretation of population structure by F-statistics with special regard to systems of mating. Evolution, v.19, n.3, p.395-420, 1965.

WRIGHT, S. Variability within and among natural population: evolution and the genetics of populations. Chicago: University of Chicago Press, 1978. v.4, 15p.

YOUNG, A.; BOYLE, T.; BROWN, T. The population genetic consequences of habitats fragmentation for plants. Tree, v.11, n.10, p.413-418, 1996. 